\title{
Environmentalism undercover: The environmental dimension of public support for domestic water charges
}

John Kenny, University of Oxford

Address: Department of Sociology, 42-43 Park End Street, Oxford, OX1 1JD, UK.

Email: john.kenny@ trinity.ox.ac.uk

\begin{abstract}
Research shows that environmental attitudes can affect support for environmentallybeneficial policies. However, it is unclear whether environmental attitudes can influence support for such policies when they are not being primarily framed through an environmental lens. Using data from the 2011 Irish National Election Study, this paper examines the issue using the case of support for the reintroduction of water charges. This was a contentious issue with debate largely focusing on the proposal as an austerity measure, but the proposal also had environmental implications. The results find that while individuals' willingness to prioritise environmental protection over economic growth did not affect their support for water charges, their willingness to make individual sacrifices for the environment did. Moreover, voters' position on this policy impacted their vote choice. The findings are particularly important given the struggles that governments are facing in implementing environmental taxes and charges.
\end{abstract}

KEYWORDS: Austerity; elections; environmental attitudes; Ireland; party competition; water charges

The Version of Record of this manuscript has been published and is available in Electoral Studies at the following link: https://doi.org/10.1016/j.electstud.2019.102088

1. Introduction

In this paper, I argue that environmental attitudes can affect support for environmentally-beneficial policies, even which such policies are not primarily framed through an environmental lens in public discourse. In recent decades, much progress has been made in understanding how environmental attitudes and concerns are formed and the impact that these have on environmental behaviour. In the domain of electoral and policy research, it has been shown that voters' environmental attitudes can have a decisive impact on national election outcomes (Bean and Kelley 1995), US representatives' record of voting in favour of environmental policy in Congress (S. E. Anderson 2011) and the adoption of renewable energy policies by European governments (B. Anderson, Böhmelt, and Ward 2017). The mechanism involves individuals with environmental attitudes becoming aware of a policy's beneficial or 
harmful environmental implications - most often through receiving information in the public sphere $^{1}$ - which then affects their views on the policy and, if such an environmental constituency becomes large enough, may have a knock-on impact on the stances taken by political representatives, parties and governments.

However, certain policies have tangible environmental benefits but are framed and debated in public discourse primarily from a non-environmental perspective. In such cases, it is unclear whether the possession of environmental attitudes can impact policy support as this would necessitate that individuals who possess environmental attitudes look beyond the primary non-environmental framing of the policy that is presented to them, recognise the environmental implications and then choose whether or not to bring their environmental attitudes to bear on the question or to continue to see the issue through the dominant, alternative frame. Choosing to see the issue through an environmental lens may be particularly onerous for individuals during a period of austerity as, though they may claim to be willing to support policies to protect the environment, their economic needs may dominate (Singer 2011).

I use public support for the introduction of water charges to answer such a question using data from the 2011 Irish National Election Study (INES). The 2011 Irish general election took place a few months after Ireland had entered into an EU-IMF bailout agreement and after considerable fiscal retrenchment had been implemented ${ }^{2}$ (Hardiman and MacCarthaigh 2013, 10). The introduction of water charges formed a substantial point of contention during the election among both voters and parties but as the campaign was 'dominated by economic issues, unemployment, terms of the financial bailout and management of the public finances' (Reidy, Suiter, and Breen 2018, 154), most of the debate revolved around the policy's

\footnotetext{
${ }^{1}$ Obtaining such knowledge may also play a role in the development of environmental attitudes to begin with. ${ }^{2}$ Between 2008 and 2011 an estimated overall fiscal adjustment of $€ 21$ billion had already been made in the context of a 2012 GNP of approximately $€ 130$ billion
} 
economic and social implications. However, from both the perspective of incentivising water conservation and providing finances to deal with outdated infrastructure that could prevent environmental damage, the policy could be expected to have tangible environmental benefits. Thus, this case provides the ideal opportunity to test whether environmental attitudes translate into support for a policy which would have a positive environmental impact when the policy is primarily being discussed through another frame and when its environmental effects are sidelined in public discourse. It is additionally a politically interesting case as the divisions seen on the policy in the 2011 election foreshadowed further politicisation of the issue in the election's aftermath. When the government attempted to implement the charges they were faced with largescale protests as well as a widespread refusal to pay campaign and they would ultimately end up abandoning the policy (Marsh, Farrell, and Reidy 2018, 5).

This is an important subject to examine empirically because, even though progress has been made, as Martinsson and Lundqvist $(2010,520)$ note, 'most existing empirical studies concentrate on the attitudinal and value dimension of ecological citizenship, and put less emphasis on whether these attitudes are also translated into environmentally responsible behaviour'. It is also one with important policy implications given the difficulties that governments are facing in implementing environmental taxes and charges.

I begin by analysing broad public support for environmental taxes and charges and providing contextual information on the Irish case before detailing the data, presenting the results and finally providing some conclusions. Specifically, I test whether individuals who professed a higher level of support for the environment were more likely to support water charges, whether any effect found differs depending on the dimension of environmental support being captured and whether support for water charges impacted vote choice. The results show that being willing to make individual sacrifices played an important role in support for the policy and that views on this policy had an impact on vote choice. 


\section{Literature Review}

I begin by examining the factors that can affect whether individuals would be willing to pay taxes or charges on a service - including water - to protect the environment. While possessing an environmental attitude is important, by its own it will not necessarily spur one into action as there often exists a gap between individuals' environmental attitudes and their environmental behaviours (Kollmuss and Agyeman 2002). Evidence from Sweden points to hypocritical individuals who profess green attitudes yet do not follow this through in their behaviour, as well as coverts who display environmental behaviour despite not possessing environmental attitudes (Martinsson and Lundqvist 2010).

Environmental attitudes themselves are also not unidimensional and depending on the aspect of support for environmental protection that one is tapping into, one may see different effects. Daniels et al (2012) identify 16 different categories of environmental attitudes, beliefs and preferences and advocate that rather than seeking to uncover a single underlying construct among these, that researchers should treat each measure as independent as they each tap into distinct judgments. Given the nature of how water charges operate, one would expect the dimension of being willing to make individual sacrifices for the environment to be the most relevant dimension, though broader environmental priorities could also play a role.

H1a Individuals who are more willing to make individual sacrifices to protect the environment are more likely to support the introduction of water charges.

H1b Individuals who prioritise the environment over economic growth are more likely to be in favour of the introduction of water charges than those who prioritise economic growth over the environment

\subsection{Sociodemographic Explanations}

There are additionally a number of important sociodemographic factors that have been shown to be related with environmentalism. Generally speaking, women report stronger environmental attitudes and behaviours than men with the effect on pro-environmental 
behaviour being consistently stronger than the effect on pro-environmental attitudes (Zelezny, Chua, and Aldrich 2000). Formal education has also been shown to be a powerful predictor of environmental knowledge, attitudes and behaviours (Diamantopoulos et al. 2003). Moreover, in examining individuals' willingness to pay higher taxes in order to protect the environment in Spain, Torgler and García-Valiñas $(2007,546)$ find that 'we have to go beyond formal education and includes individuals' interest for current political matters or other proxies of political awareness'.

\subsection{Economic, Financial and Social Explanations}

Having the financial means to pay may also be a factor. In cross-national studies, it has been shown that - within countries - individuals with higher incomes are more willing to pay for environmental protection (Fairbrother 2013) and climate change (Mayer and Smith 2017). It is also posited that environmental protection is a luxury good that people value during good economic times when they feel they can afford it but deprioritise when the economy declines (Abou-Chadi and Kayser 2017). In support of this, an experimental study in Britain shows that individuals are more likely to prioritise action on climate change when they perceive the economy to be performing well (Kenny 2018). Thus, during harsh economic conditions it may be particularly onerous for individuals to support costly environmental policies.

When it comes to water charges specifically, introducing water charges that aim towards full cost recovery is particularly beneficially for altering consumer behaviour. Doing so shows the consumer the resource's cost and dispels perceptions that it is cost-free which may prove especially effective in encouraging water conservation during the more price-elastic summer months (OECD 2003, 52). Despite the potential such a policy has for water conservation, the public may be more sceptical of such an outcome occurring. Dresner et al. (2006, 901) find that the public see environmental taxes more broadly 'solely as a means of 
raising revenue, rather than in terms of their incentive effects' and that 'many people could not understand that a tax on energy would have benefits for the environment even if the revenues went to labour tax reductions'. Additionally, focus groups have shown that some people question environmental taxes if they do not have any effect on behaviour (Kallbekken and Aasen 2010, 2189), with such reservations having the ability to be offset if the money raised is earmarked for environmental purposes (Kallbekken and Sæælen 2011, 2967). Recent evidence from the UK however finds that the earmarking of such revenue for environmental protection in general does not increase support for environmental taxes, speculating that the specificity of environmental earmarking may be important (Fairbrother 2019).

One reason for introducing water charges can be to raise money that is earmarked towards addressing infrastructural issues in the water network which would have many environmental benefits. However, users are less willing to pay for water tariffs if they believe they are being charged for inefficiencies within the system (OECD 2009, 50). Thus, the irony of the finding that earmarking money raised by environmental taxes for environmental purposes may increase support for water charges is that it may be necessary to introduce water charges to address system inefficiencies, but users may be even less willing to be charged if the inefficiencies have not been addressed first.

While the economic and environmental implications of the proposal for introducing water charges have been discussed, the social dimension is also important. Water is needed to provide for basic human needs and thus introducing charges may particularly affect households that are already struggling financially. The OECD (2003) notes that if poorer individuals are finding their water bills to be too expensive, they may reduce their consumption to levels that do not provide for their basic needs which in turn may negatively affect public health and/or increase levels of financial stress. While from an income equality perspective one would expect 
that poorer households should not pay a bigger percentage of their income on water services, in reality water charges inevitably lead to such an outcome. Barth, Finseraas and Moene (2015, 566) posit that when voters below the mean income level experience declining incomes, they may feel the burden of attending to their urgent, material needs and may be less willing to pay higher taxes to finance welfare spending. Thus, especially in the context of increasing financial insecurity, one would expect that lower income households would be amongst the least supportive of water charges.

$\mathrm{H} 2$ Individuals who are most likely to be experiencing the greatest financial hardship will be among the least likely to support the introduction of water charges.

\subsection{Ideology and Partisanship}

The role of ideology and partisanship must also be considered. Traditionally, left-leaning or liberal individuals are more disposed towards environmental protection than right-leaning or conservative individuals (Van Liere and Dunlap 1980), though the relationship has been found to differ in its consistency across different cross-national contexts (Fairbrother 2016). Research from Sweden suggests that such an effect is largest when individuals are confronted with an explicit environmental-protection and economic growth trade-off (Harring and Sohlberg 2017).

Above individuals' ideological leanings, the positions that parties take can be important. While parties campaign on issues they have a positional advantage on, they also gravitate towards issues that are salient to the public (Green and Hobolt 2008, 464). During a period of austerity, one would expect parties to frame their policy positions through a pro- or antiausterity lens that is likely to resonate with public sentiment. Once parties have decided on their platforms, Carsey and Layman (2006) demonstrate that if individuals are aware of party differences but do not find the issue to be particularly important that they should bring their 
own attitudes in line with the party position. However, when they are aware of party differences on an issue and deem it to be important, they may switch their party allegiances to match their issue preferences. Applying this to water charges, one would expect partisanship to matter for approval of water charges whether it is the case that those with strong preferences on the policy vote for parties that hold the same position or whether those that did not hold strong preferences updated their preferences to reflect that of their party.

H3 Individuals who support parties campaigning for the introduction of water charges are more likely to support water charges themselves than individuals who support parties campaigning against the introduction of water charges.

Following on from this literature review, I will now present the details of the Irish case that is the focus of the paper.

3. Water Charges and the 2011 Election in Ireland

December 1996 saw the announcement of the abolition of domestic water and sewerage charges in Ireland, with the costs of water supply subsequently provided through general taxation. The charges had become unpopular amongst certain sectors for reasons including fixed charges due to the absence of meters and thus the lack of a relationship between charges and quantity used, the large bills when they arrived due to infrequent billing and a lack of a standardised method for dealing with vulnerable families (Scott 2003). Growing opposition and the rise in electoral support for anti-water charges candidates as evidenced in by-elections in the run up to a general election placed pressure on the government to react which paved the way for abolition.

Such a policy was detrimental for the financing of water infrastructure. When water systems are operating inefficiently and have an insufficient amount of revenue, one can expect inadequate operation and maintenance of infrastructure which will eventually have a knock-on 
effect on services (OECD 2009, 50). Though Ireland has plentiful water resources, a lack of investment had left the infrastructure outdated and led to serious leakage problems. The average age of Irish water mains is 65-85 years compared to a European average of 36 and the country had a 2011 average leakage rate of 41 per cent compared to the usual OECD range of 10-20 per cent (Expert Commission on Domestic Public Water Services 2016, 7/8; OECD 2009, 49). The infrastructural issues also have further impacts on substandard water treatment, with a 2017 report from the Environmental Protection Agency finding that 44 urban areas were directly discharging raw sewage with harmful effects for public health, aquatic ecosystems and the waters' amenity value (Environmental Protection Agency 2017). The decision to abolish domestic water charges also came at the beginning of the Celtic Tiger period of rapid economic growth which increased the strain and demand on the system in tandem with government policies that failed to encourage conservation (Zhao and Crosbie 2012, 429). Thus, while a populist policy that may have been electorally pleasing, abolishing domestic water charges was not economically or environmentally beneficial.

While an outbreak of Cryptosporidium hominis in the Galway area in 2007 due to inadequate water treatment and its detrimental economic, environmental and social effects (Morris et al. 2016) brought high public salience to the issue of water infrastructure and its deficiencies, it was not until the economy entered into recession following the 2008 financial crisis that domestic water charges seriously returned to the political agenda, primarily as a finance-raising mechanism. The speech for the 2010 budget announced that the then Fianna Fáil-Green Party government was preparing to introduce water charges to broaden the tax base which would be based on consumption above a certain free allowance (Lenihan 2009). Upon entering into an EU-IMF bailout deal twelve months later, the government further set out that it was 'planning to move towards full cost-recovery in the provision of water services' (Ireland 2010,8 ) as well as moving water provision from local government to a centralised water utility. 
This set the scene for the introduction of water charges to play a major part of the general election campaign of February 2011.

Before detailing the parties' stances on water charges, it is helpful to provide some context on the political parties and the nature of party competition in Ireland. Fianna Fáil was the dominant party from 1932 to 2011 and had never been out of government for more than one consecutive election up until this point. Its policy platforms are so similar to those of its main rival Fine Gael - the only other party to lead a government - that it is often difficult to define what differentiates the two parties. Each party combines elements of conservatism, Christian democracy and social democracy and are best classified as 'catch-all' parties (Weeks 2010). The Labour party has existed in the shadow of Fine Gael and Fianna Fáil and, despite being a social democratic party, its support base had become increasingly cross-class over the latter decades of the $20^{\text {th }}$ century. Where social bases of support were most clearly seen prior to the 2011 election was in support for the smaller parties of Sinn Féin who received more support from working-class and the Green party who received more support from middle-class voters (Marsh 2010).

An unusual feature of the Irish system is its remarkably low levels of partisanship which have been steadily declining in recent decades. In 2007, only a quarter of voters reported feeling close to a party whereas the equivalent range in countries across Western Europe, North America, New Zealand and Australia is between 50 and 80 per cent (Marsh 2010, 172). With such low levels of party attachment, as Marsh et al $(2008,79)$ noted following analysis of the 2002 INES data, 'short-term factors therefore have an increasing potential to make a big impact on Irish elections'. Taken together with the finding that potential support for each party is shared across at least one competitor and 'most voters could be said to be effectively 'in competition', fought over by several parties' (Marsh 2010, 169), issue controversies may matter more in Irish elections even during 'regular' elections. 
The 2011 general election was not a regular election though, being described as 'Ireland's earthquake election' (Gallagher 2011) due to a dramatic realignment of the party system. Fianna Fáil lost their dominant position with a historically low vote share - down over 24 per cent on the previous election - having received the blame for the country's severe economic downturn and their junior coalition party - the Green Party - lost all of their six seats. Indeed, the election had been the third most volatile election to have occurred among longstanding European democracies since 1945 and unusually one that did not result in the establishment of any new major party (Mair 2011). While the initial defection concerned performance politics, the destination of the defection was about positional politics (Tilley and Garry 2017,20 ) and thus the policy signals that opposition parties sent out were even more important than usual in attracting voters.

With the environment being a low salience issue in the election - evidenced by only one respondent in the 2011 INES mentioning environmental issues as the most important issue to them personally - and issues of the economy and austerity dominating, these latter frames were where more votes could be expected to be won and it is through this lens that parties justified their positions on water charges. The Labour Party, Sinn Féin and the United Left Alliance $^{3}$ all framed their opposition to water charges through the lens of the financial burden that such charges would place on struggling households, with the Labour Party additionally pointing out that the water infrastructure should be improved before any metering is implemented, tapping into the sentiment referred to previously that individuals may be particularly against water charges if they feel they are being charged for an inefficient service. While the Labour Party also contained separate, explicit environmentalist appeals in its manifesto, such commitments were almost completely absent from Sinn Féin's manifesto.

\footnotetext{
${ }^{3}$ An alliance of smaller socialist parties.
} 
Meanwhile, Fine Gael and Fianna Fáil both supported the policy primarily from the perspective of raising revenue for the troubled public finances. While Fine Gael did commit to using revenues garnered from the charges to fund the delivery of clean and safe water, the policy was also contained in the section of their manifesto entitled 'Cutting the Deficit by Broadening the Tax Base'. The only mention of water charges in the Fianna Fáil manifesto was the economic benefits the installation of water meters would provide through creating jobs, though their renewed programme for government a few months previously had also touted it as a means to raise local government revenue. Thus, for both of these parties, environmental motivations were not the drivers of their support. The only party to explicitly campaign for water charges primarily on an environmental front was the Green Party, who was also the only party to emphasise in their manifesto the conservation impact that the introduction of water charges could have through altering consumer behaviour.

In this electoral environment, it is quite a hard test to see whether individuals' environmental attitudes could impact their support for the policy when its environmental implications received at best peripheral attention in the campaign.

\section{Data}

This paper uses data from the 2011 INES. The survey was carried out in the aftermath of the general election on a representative national sample through face-to-face interviews with a total of 1,853 respondents. A self-complete drop-off questionnaire was additionally included, which 91 per cent of respondents completed (see Marsh, Farrell, and McElroy 2017 for further details on the survey and the survey questionnaire). When analysing the data, I make use of the demographic and political weights provided. This section details the questions being utilised in the analysis. 


\subsection{Dependent Variable}

The dependent variable asks, 'Thinking about each of the following, and bearing in mind that government might need more revenue in order to maintain spending levels on public services, would you be in favour of, or opposed to, the introduction of each one of these measures in order to raise revenue for the public finances? - water charges ${ }^{4}{ }^{3}$. The responses were in favour, opposed or don't know ${ }^{5}$. The frame focuses individuals' minds on the harsh economic conditions the country was experiencing and whether the introduction of specific finance-raising measures was a favoured solution. Thus, in some ways, this question could be seen as measuring pro- versus anti-austerity sentiment. However, if one was sympathetic to the introduction of water charges primarily from an environmental perspective, one would still expect such respondents to answer that they were in favour of such a charge. If the environmental perspective was to encourage water conservation, then if that was achieved alongside an increase in public revenue through the introduction of water charges, the financial benefits for the state would be a desirable by-product. And if the environmental perspective was that the money raised could be reinvested back into water infrastructure to improve the quality and supply of water, then such a policy may also be desirable.

\subsection{Independent Variables}

I use three environmental measures, each of which taps into a different environmental dimension, to examine whether environmental attitudes impacted support for water charges. The first question taps into individuals' willingness to sacrifice their standard of living to protect the environment by asking them to place themselves on a scale from strongly disagree (1) to strongly agree (7) in response to the statement, 'I would be willing to accept a cut in my

\footnotetext{
${ }^{4}$ The other measures in this battery were property tax, the sale of state assets and the reintroduction of student fees. The order in which these were read was rotated.

${ }^{5} 67$ respondents - representing 3.6 per cent of the full sample - answered 'don't know' to this question and have been treated as missing.
} 
standard of living in order to protect the environment' ${ }^{6}$. The second question asks respondents on the same 1-7 scale to respond to the statement that, 'I would be willing to pay much higher taxes in order to protect the environment'. A key difference between these questions is that though respondents indicate a willingness to take on a significant extra tax burden to protect the environment, by doing so they do not necessarily foresee that this will negatively affect their standard of living. These two variables are moderately correlated at a value of 0.38 . The third question taps into a policy-level trade-off by asking respondents to place themselves on a scale between 'We should encourage economic growth even if this damages the environment' (recoded as 0 ) and 'We should protect the environment even if this damages economic growth' (recoded as 10). In the context of the question, those who answered 'don't know' have been treated as the middle category ${ }^{7}$. The trade-off dimension is weakly correlated to each of the first two environmental indicators with correlation coefficients of 0.14 and 0.12 respectively. All of these questions were asked in different parts of the questionnaire.

Partisanship is primarily measured using the party respondents feel close to and, if respondents said no to this question, if there is any party they feel closer to than others. With this question, one is able to approximate partisan identity. This is categorised into Fianna Fáil, Fine Gael, the Labour Party, Sinn Féin, and other/none ${ }^{8}$. The party one gave their first preference vote to/would have given their first preference vote to if they did not vote is also used both as a robustness check and for other analysis with the same categories, with the exception that 'other' is separated from 'refused/don't know' categories due to 'other' being large enough to include as a standalone category. Finally, as a further robustness test, I use a

\footnotetext{
${ }^{6}$ This question was part of the drop-off questionnaire

${ }^{7}$ For robustness, I have carried out the subsequent analysis where these respondents are instead treated as missing and neither the co-efficient nor the p-value changes substantively.

${ }^{8}$ The other category [including those that felt closer to a particular party but would not name the party] only contained 23 individuals between the various parties which is why this category was merged in with those who responded 'none'.
} 
series of questions asking respondents how likely they are to ever give their first preference vote to each political party on a 0-10 scale (those who answered 'don't know' have been coded as the middle category 5) which captures electoral utility (van der Eijk et al. 2006). This allows me to examine whether individuals' views on water charges were associated with how they considered all parties as opposed to restricting their choice to the party they voted for or felt closest to. It importantly allows me to include small but notable parties - namely the Green Party and the United Left Alliance - who played a visible role in the election campaign but did not receive enough national level support to give reliable estimates through the questions in the other models.

To capture individual hardship, the following measures are used: Annual gross household income ranging on an eight-point scale from less than $€ 20,000$ to greater than $€ 75,000^{9}$; employment status (full-time employed, part-time employed, unemployed and seeking work, student, retired and engaged in home duties); and accommodation type (home owner without a loan or mortgage, home owner with a loan or mortgage, local authority tenant, private tenant and other). Accommodation type is relevant as a number of individuals were living in negative equity following the collapse of the housing bubble.

To capture respondents' subjective perceptions on the tax versus spending scale - as one would expect that individuals who are more supportive of increasing taxes in general would also be more supportive of introducing water charges - I use the question, 'I would like you to look at the scale from 0 to 10 on this card. A ' 0 ' means government should MAINTAIN TAXES and SPEND LESS on health and social services, and '10' means government should INCREASE TAXES A LOT and SPEND THE SAME on health and social services. Where would you place yourself in terms of this scale?'. In the context of the economic conditions,

\footnotetext{
${ }^{9}$ While originally asked on a 10-point scale, the three highest categories of $€ 75,000-€ 99,000, € 100,000-€ 149,000$ and $€ 150,000+$ have been merged together due to power issues.
} 
this question confronts respondents with the reality that maintaining taxes may not mean maintaining the same level of services. Those who responded 'don't know' to this question have been classified as equivalent to those who answered the middle ' 5 ' category.

A number of controls are also used. Age is included as a continuous variable, gender as being either male or female and formal education is included using a question that asked individuals to state their highest educational level achieved to date (primary, junior certificate or equivalent, leaving certificate or equivalent, diploma or certificate and university degree or equivalent). To capture political interest, I include individuals' subjective interest in politics ranging from 'not at all interested' (1) to 'very interested' (4) and political awareness is proxied by the number of days per week respondents listen to national radio news.

In addition to examining determinants of support for water charges, at the end of the paper I examine whether support impacted voters' first preference choice. Additional controls used here include social class (ab, c1, c2, d, e, f50+, f50-), living in an urban or rural area, objective political knowledge (on a scale from 0-3 where 0 means individuals got three political questions wrong and 3 means that individuals got 3 political questions right), belief in God (on a scale of 0 'definitely does not exist' to 10 'definitely does exist' with 'don't knows' recategorised as ' 5 '), what one considered to be the most important issue for the respondent in the election (coded into being let down by the political system, public services, macroeconomy/public finances, employment/labour, taxes/personal cuts and other/don't know) and whether the respondent considered the change in the state of the economy over the past four years to have been mainly due to government policy, not mainly due to government policy or that they don't know.

\section{Results}

I begin by presenting some descriptive statistics. In Table 1, one can see the reported levels of support for water charges broken down by one's vote/intended vote in the 2011 
general election. The policy was unpopular amongst the majority of the population. Overall, only 35 per cent were in favour of it. However, this is still relatively substantial given that signing up to new charges is unlikely to be popular at the best of times, never mind during a period of intense economic and financial insecurity ${ }^{10}$. While no party had a majority of their supporters in favour of the charge, parties in favour of the policy have bigger proportions of their supporters who are in favour with 41 per cent for Fine Gael and 39 per cent for Fianna Fáil voters. On the other end of the spectrum, support was only 13 per cent among Sinn Féin voters. Meanwhile, support is closer to the average for both Labour Party voters and voters of 'other' parties and independents. Thus, at an initial glance, partisanship is playing a role as expected.

Table 1: Support for Water Charges by 2011 Vote/Vote Intention (\%)

\begin{tabular}{lllllllll}
\hline & FG & FF & Lab & SF & Ind & Other & None & All \\
Party Position on Water Charges & For & For & Against & Against & N/A & N/A & N/A & N/A \\
Support & 41 & 39 & 34 & 13 & 34 & 34 & 33 & 35 \\
Opposition & 59 & 61 & 66 & 87 & 66 & 66 & 67 & 65 \\
\% Column Total & 100 & 100 & 100 & 100 & 100 & 100 & 100 & 100 \\
Number of Respondents & 615 & 293 & 328 & 168 & 207 & 102 & 73 & 1786 \\
\hline
\end{tabular}

To ascertain whether environmental protection preferences played a role in support for water charges, figure 1 breaks down each of the three environmental protection questions into whether individuals gave an environmental response, the midpoint answer or a nonenvironmental response and within each of these categories displays the percentage of respondents that expressed support for or opposition to the introduction of water charges. From the first chart, it appears that those who disagree with accepting cuts in their standard of living to protect the environment are less likely to support water charges than those who would agree to cuts or are unable to decide. The second chart shows that those who agree to paying higher taxes to protect the environment are more likely to support water charges than those who

\footnotetext{
${ }^{10}$ The level of support for the other items in the battery were 40 per cent for the sale of state assets, 22 per cent for property tax and 14 per cent for reintroducing student fees.
} 
disagree to paying such taxes or are undecided. Finally, there is very little difference in support for water charges among those who would choose to either prioritise economic growth or environmental protection. Though preliminary, it appears that the environmental dimension related to making personal sacrifices for the environment may be the dimension that matters for supporting water charges.

Figure 1: Support for Water Charges by Measures of Environmental Support

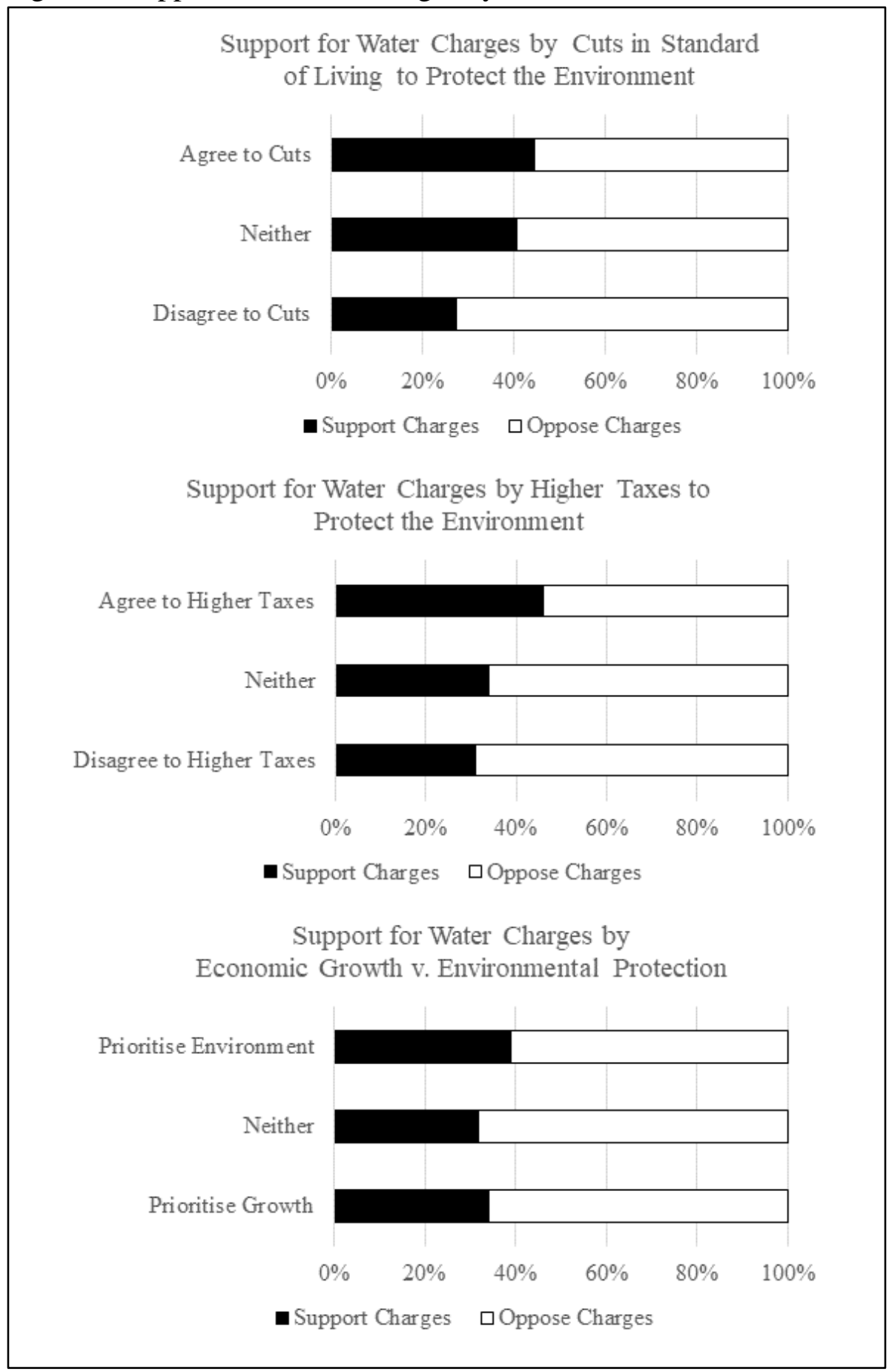




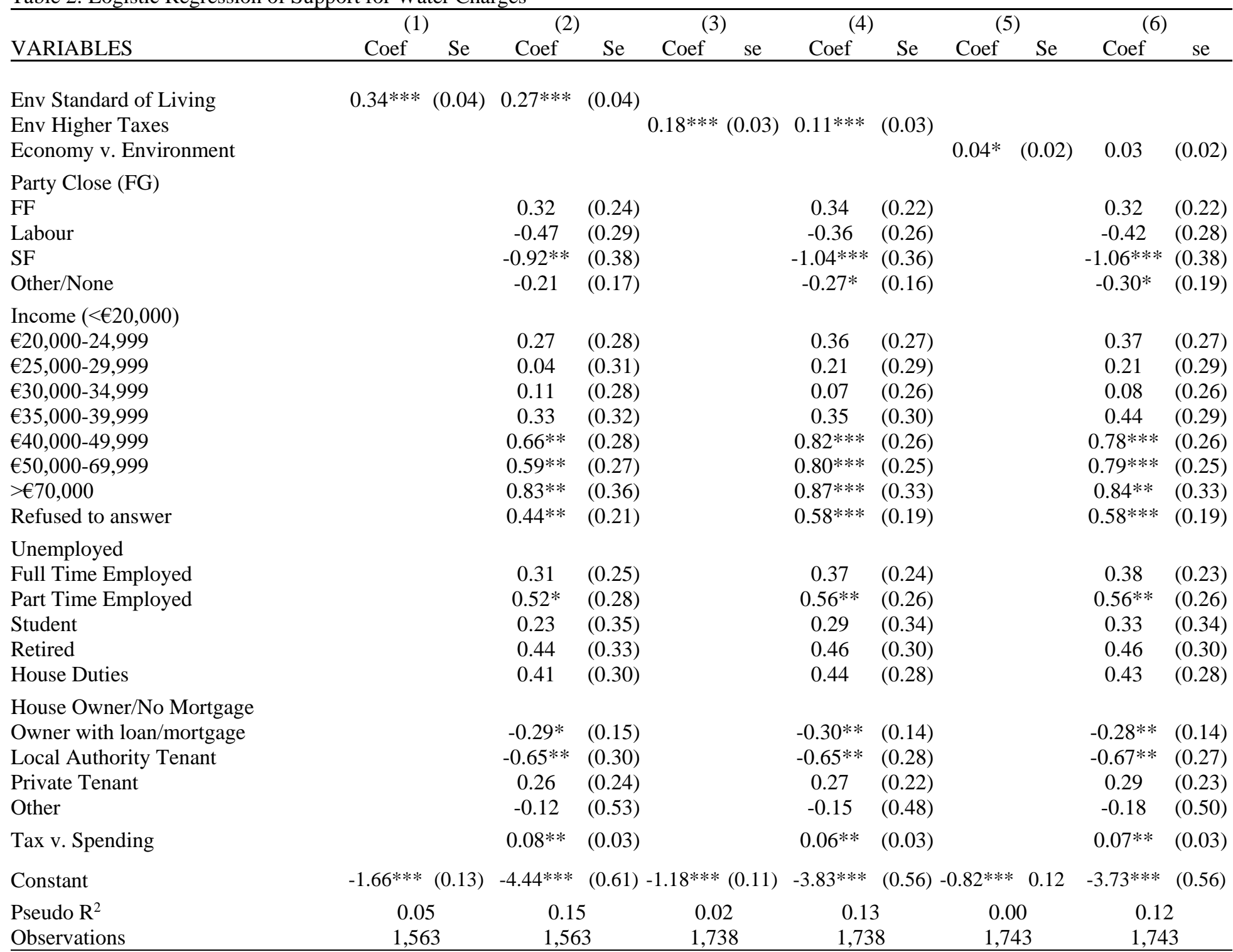

\section{Robust standard errors in parentheses} $* * * \mathrm{p}<0.01, * * \mathrm{p}<0.05, * \mathrm{p}<0.1$

Note: The following controls as described in the data section (age, gender, education, political interest and the number of days per week respondents listen to national radio news) are included in the model but the coefficients are not displayed in the table due to reasons of space. The full models can be found in the online appendix in Table A1

Table 2 presents logistic regressions carried out with the dependent variable being support for water charges. Each model contains just one of the environmental protection measures firstly on their own and secondly with the inclusion of the other independent variables. The results demonstrate a significant relationship between support for water charges and respondents' stated willingness to make personal sacrifices for the environment both when they are included on their own and when the other explanatory and control variables are added 
in $^{11}$. The strength of this relationship is greater for being willing to accept a lower standard of living than for being willing to pay much higher taxes. However, respondents' willingness to prioritise environmental protection over economic growth does not affect their support. This suggests that respondents have the ability to differentiate between micro- and macro-level environmental actions and to then link the micro-level environmental actions with paying for water. Thus $\mathrm{H} 1 \mathrm{a}$ is accepted and $\mathrm{H} 1 \mathrm{~b}$ is rejected.

Next, I examine the coefficients for the party one feels close to. Here, support for water charges is not statistically significantly different between supporters of the Fine Gael and Fianna Fáil parties who both advocated for such a policy. However, supporters of Sinn Féin a party that was against the water charges - are significantly less likely to support the measure, and while the coefficient for the Labour party - a party that was also against the charges - is not statistically significant compared to the reference displayed of Fine Gael partisans as displayed, it is significant at the $\mathrm{p}<0.05$ level compared to Fianna Fáil partisans. While this party closeness variable is the most appropriate for capturing partisanship, as a robustness test the models were also run using the party individuals gave their first preference vote to (see online appendix Table A2) and similar findings emerge with the main difference being that there is a statistically significant difference between Labour Party voters and Fine Gael voters in these models ${ }^{12}$. Thus, $\mathrm{H} 3$ is accepted.

On experiencing financial hardship, the indicators generally show that such individuals are less likely to support water charges. Higher income earners are more likely to support the

\footnotetext{
11 The relationship additionally remains robust if any single explanatory or control variable is removed.

12 As a further robustness test, a set of models substituted this question for questions asking respondents how likely they are to ever give their first preference vote to each political party. These models show (see online appendix Table A3) that individuals' preferences for the introduction of water charges maps onto their dispositions towards each of the parties in that those who support the policy are more likely to be willing to give their first preference vote to parties who also support the policy (significant at the $\mathrm{p}=0.05$ level in all models for likelihood to ever give first preference vote to Fianna Fáil and the Green party, though only at the 0.10 level in some models for Fine Gael) while being less likely to support parties that opposed the policy (significant at the $\mathrm{p}=0.01$ level for likelihood to ever give first preference to Sinn Féin and the United Left Alliance, though only at the $\mathrm{p}=0.10$ level for the Labour Party).
} 
policy, local authority tenants are the least likely to support the policy and, though the significance levels are inconsistent across the models, there is some indication that home owners with loans/mortgages are less likely to support water charges than those without such burdens. Employment status does not behave as expected, with the unemployed only being significantly less likely at the $\mathrm{p}<0.05$ level than those who are part-time employed to support the charges and at that only in two of the three models.

To demonstrate the magnitude of these effects, predicted probabilities are calculated based on models $2 \& 4$ where significant effects were found for the respective environmental questions, keeping every other variable at their mean value. These are plotted in figure 2 . In each case, as one's answer to the environment question increases, one's probability of supporting water charges also increases. The effect is more pronounced for the cuts to standard of living question where keeping everything else in the model at its mean value, one has a 22 per cent probability of supporting water charges if one responds lowest on the environmental scale, whereas the corresponding figure for those who respond highest on the environmental scale is 58 per cent. For the willingness to pay taxes to protect the environment questions, if one is highly unwilling to pay taxes for this purpose, keeping everything else in the model at its mean value, one has a 27 per cent probability of supporting water charges whereas the corresponding figure for those who are highly willing to pay taxes for this purpose is 42 per cent. 
Figure 2: Predicted Probabilities of Supporting Water Charges by Environmental Attitudes
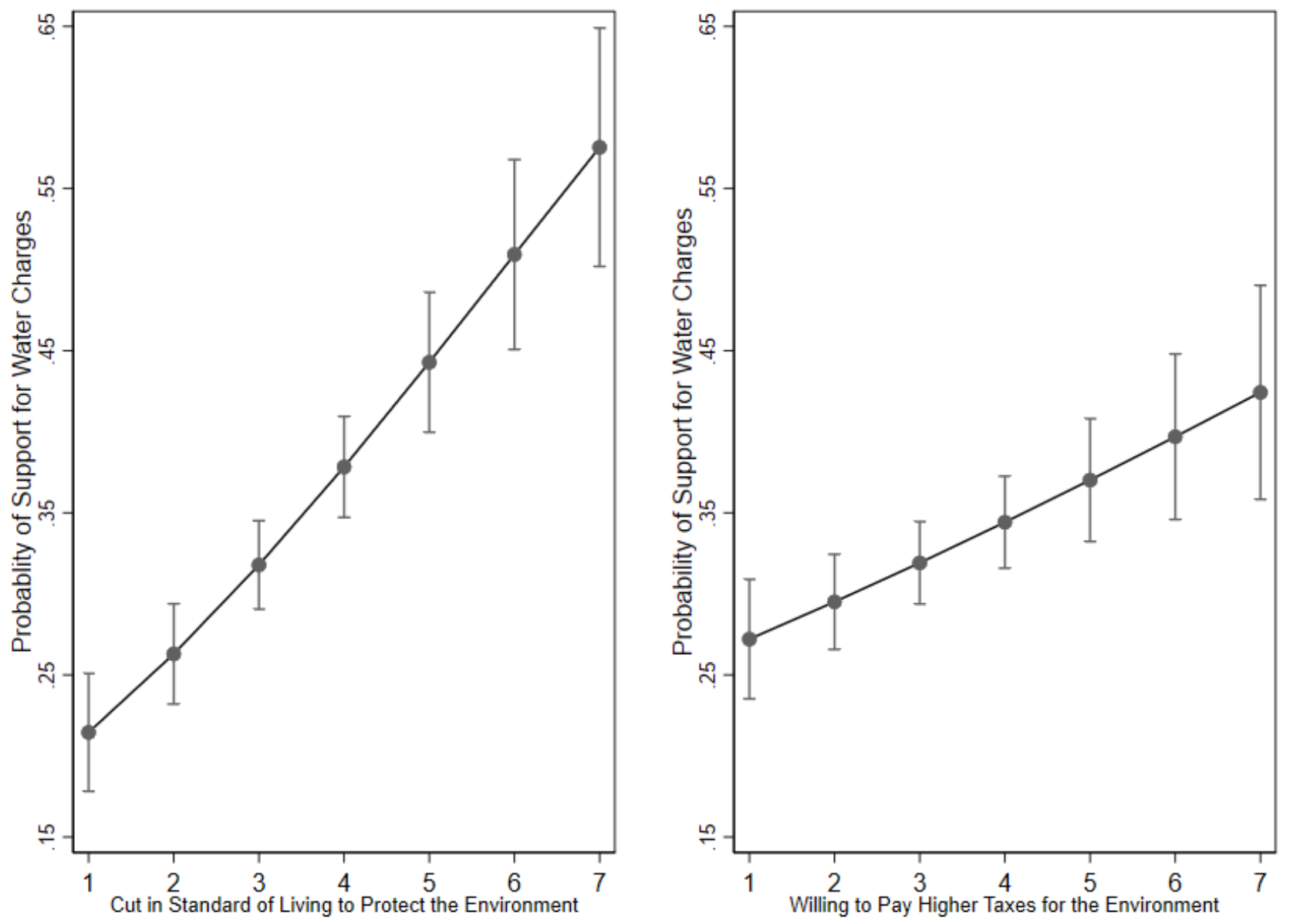

A further point of curiosity is found in an additional test (Table A4 in the online appendix) in which partisanship is interacted with the environmental support variables. Here, though Labour Party partisans are in general less likely to support water charges in line with party policy, Labour party partisans who are more willing to make individual sacrifices for the environment are more likely to support the policy. This highlights some polarisation among Labour party partisans. On the one hand, some may have evaluated the policy based on the socialist lens upon which the party based their policy position or indeed just followed the party cue. On the other hand, as the Labour Party also promotes environmental protection, members who are disposed towards environmental protection appear to have ignored party cues and instead made their judgment independently based on environmental considerations. Such an effect is not present for other partisans, though it is present for nonpartisans. 
One lingering concern is that the environmental questions could capture more of a willingness to 'make sacrifices for the common good' dimension rather than tapping specifically into a willingness to make sacrifices for the environment. As previously mentioned, the water charges question was asked as part of a battery that also asked about support for property tax, selling state assets and reintroducing student fees to raise revenue for the public finances. Applying my models on these policies that do not have an environmental element - as I have done in Tables A5-A7 in the online appendix - allows the opportunity to more robustly test my theory.

While not significant for supporting the reintroduction of student fees, both of the individual-level environmental variables - though not the macro-level trade-off variable - are positively correlated to support for the sale of state assets, though being willing to accept a cut in one's standard of living to protect the environment - with a coefficient of 0.11 - is at a much lower magnitude than the coefficient of 0.27 in the water charges model. For supporting property tax, all three environmental variables are statistically significant. Being willing to accept a drop in one's standard of living is still at a much lower magnitude, but the magnitude of the coefficient for being willing to pay higher taxes at 0.22 is notably higher. Given the moderate correlation between support for water charges and property tax $(0.38)^{13}$ it should not be surprising that they should share some of the same correlates, though it raises the question as to whether environmental dispositions are playing a role in support for water charges beyond a general 'willingness to sacrifice' element.

There are good reasons to believe that they are. Firstly, the environmental question that taps into the biggest individual-level sacrifice - being willing to accept a drop in one's standard of living - is by far the most important environmental indicator of support for water charges,

\footnotetext{
${ }^{13}$ Support for water charges correlates at 0.28 and 0.18 with support for the reintroduction of student fees and the sale of state assets respectively.
} 
while being less important for the other policies. Secondly, political interest and awareness are known correlates of a willingness to pay environmental taxes (Torgler and García-Valiñas 2007) and out of the four policies analysed, my indicators of these are only consistently significant for water charges support (see online appendix Tables A1;A5-A7). Thirdly, I have shown that Labour partisans - a party who had both environmentalist and socialist appeals that were more willing to make individual sacrifices for the environment were more likely to support water charges against the party's official position. As Table A8 in the online appendix shows, there is no such interaction effect between being a Labour partisan and expressed environmental positions for support for property taxes; a policy for which Labour partisans' environmental views should not divide them. Thus, while a general willingness to make sacrifices for the common good may be captured by the environmental questions - which explains their significant association with support for some of the other policies - the evidence also points to a clear environmental dimension in water charges support beyond this.

While this paper has shown that environmental attitudes can explain support for water charges, a final question is whether support for water charges affected vote choice. To examine this, a multinomial logistic regression is carried out in which the dependent variable of individuals' reported actual or intended vote is regressed on a range of variables that could influence vote choice plus the water charges question. If the water charges question has a statistically significant impact upon vote choice after controlling for all of these other variables, then one can be confident that attitudes towards the proposed policy had an impact upon voter behaviour. In a second model, the variable of respondents' reported first preference vote at the 2007 general election is included. This is one of the best predictors for explaining current vote preference and so including this provides an even stronger test on whether voters' views on water charges influenced their vote choice as well as an opportunity to approximate whether parties' positions on this policy enabled them to attract new voters. 
Figure 3 displays the coefficients for the support for water charges variable that is of interest from these models with Fine Gael being used as the reference category ${ }^{14}$. In the first model that does not include respondents' reported vote choice at the previous election one can see that whether or not one supports water charges is a statistically significant distinguishing factor in voting behaviour with individuals who voted for the Labour Party or Sinn Féin over Fine Gael being less likely to support the introduction of domestic water charges in line with party policy. The water charges variable is not a significant indicator for explaining why one voted for Fine Gael over Fianna Fáil - both of which supported the introduction of the policy and neither is it for voting for independents or others over Fine Gael which could be expected due to the different policy positions taken within each of these categories on the policy ${ }^{15}$.

In the second model, the party individuals reported giving their first preference to in the previous general election is included. Notably, this results in the pseudo $\mathrm{R}^{2}$ increasing from 0.12 to 0.28 indicating its importance for explaining one's 2011 first-preference vote. The water charges variable is no longer statistically significant in this model for explaining why people voted for the Labour Party, indicating that their stance on this issue was not important for attracting new voters. From the data, one cannot say for definite whether it may have been important for retaining existing voters. The coefficient remains statistically significant for explaining why one voted for Sinn Féin over Fine Gael (as well as other parties with a change of baseline) with a sizeable magnitude, suggesting that the party's stance on this played a key role for them in attracting new voters. As Sinn Féin distinguished themselves from the other

\footnotetext{
${ }^{14}$ The output for the other variables can be found in the online appendix in Table A9 for the first model and Table A10 for the second model.

${ }^{15}$ If the reference category is instead set as Fianna Fáil, support for water charges is not a statistically significant indicator for distinguishing voting for Fianna Fáil over Labour in the model. However, given the negative campaigning that was engaged by the Labour Party in the closing stages of the campaign with their 'Fine Gael Every Little Hurts' slogan that specifically attacked Fine Gael's austerity measures including water charges (Leahy 2011, 85/86) - and given the other variables in the model including the economic voting indicator that one would expect to be the key differentiator between Fianna Fáil voters and Fine Gael/Labour voters - this is not so surprising.
} 
main parties by rejecting the bailout agreement outright (Gallagher 2011, 150) of which the proposed introduction of water charges was a well-known component of, the significance of water charges for the Sinn Féin vote likely reflects their success in positioning themselves as a vehicle for anti-austerity votes. Thus, these models suggest that support for the reintroduction of water charges had an important role to play in individuals' vote choice, but only unambiguously so for Sinn Féin.

Figure 3: Support for Water Charges Coefficients from Multinomial Logistic Regression models explaining 2011 General Election First Preference Vote/Vote Intention

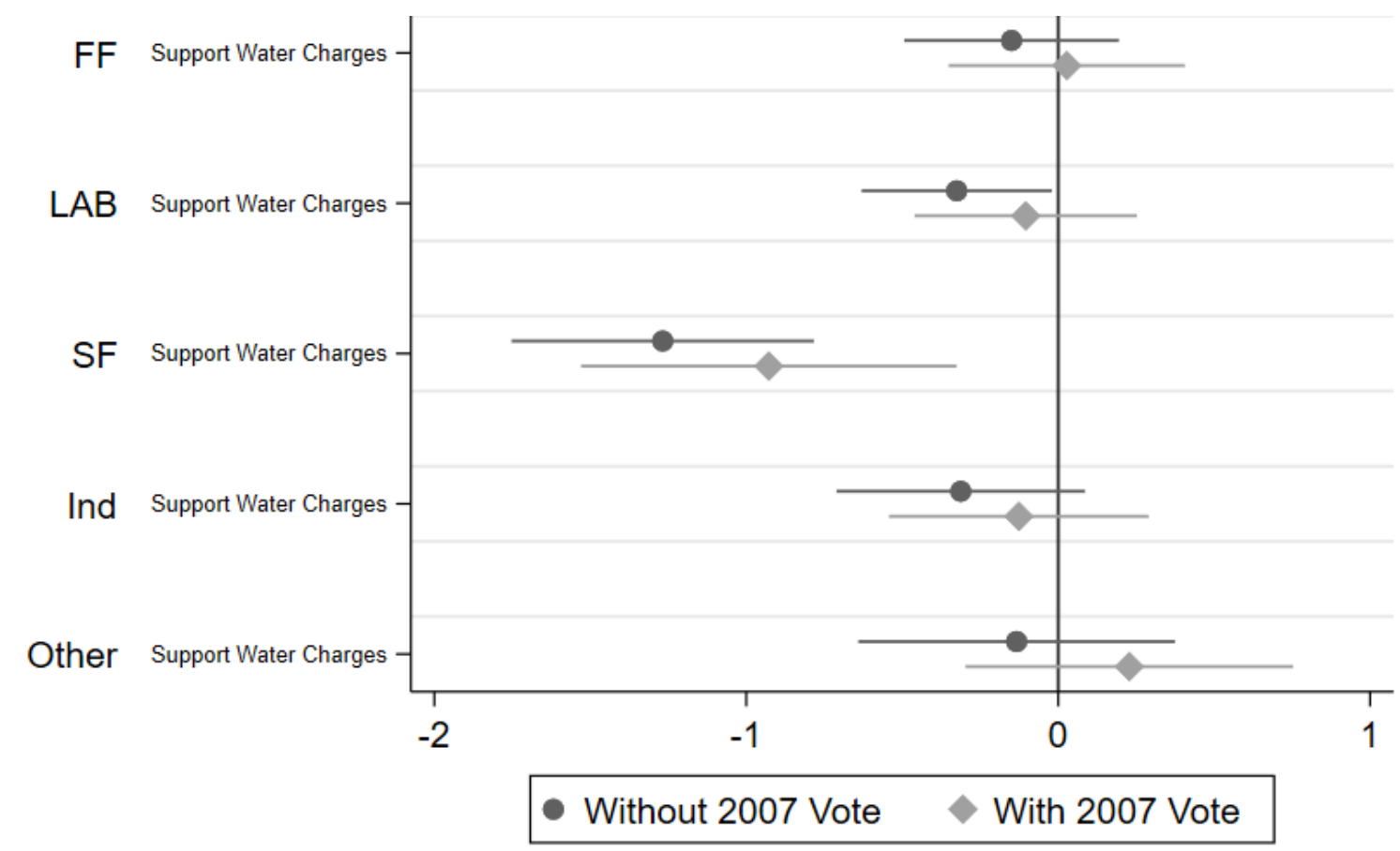

Note: The reference category in the multinomial logistic regression is Fine Gael. The figure displays the coefficients for support for water charges with $95 \%$ confidence intervals. In addition, both models contain additional control covariates. Tables displaying the full outputs can be found in the online appendix in Tables A9 and A10.

\section{Conclusion}

In this paper, I demonstrate that a willingness to make individual sacrifices for the environment was related to greater support for the reintroduction of water charges in Ireland in 2011. The magnitude of the effect is greater for being willing to sacrifice one's standard of living for the sake of the environment than being willing to pay higher taxes for the environment. Meanwhile, the macro-level trade-off dimension between prioritising economic 
growth over environmental protection has no effect. Given that the policy would involve individuals being financially worse off from the policy, it appears that it is individuals' willingness to bear such a burden if they can expect it to lead to environmental gains that matters.

These results are especially important given the unfavourable context that made it a particularly hard test. Ireland was in the midst of a severe economic crisis and had recently entered into an EU-IMF bailout deal having already implemented a number of substantial austerity measures over the previous years. Despite the environmental benefits of the policy in encouraging water conservation and raising revenue to address infrastructural problems, under such bleak conditions the economy dominated even more than usual. While the proposal received prominent attention during the election campaign, the environmental aspects of the policy were not prominently highlighted with debate instead focusing on its economic and social implications. Thus, it was quite an onerous task for individuals to bring their environmental attitudes to bear on their support for this environmentally-beneficial policy when its environmental consequences were side-lined in the election campaign and the framing of the question they answered focused on the proposal as a finance-raising mechanism. The fact that an association was found between support for water charges and environmental attitudes under such conditions is particularly compelling.

I also investigated whether support for the policy may have influenced vote choice in the 2011 general election, which was especially important given the high level of electoral volatility. While such an effect on vote choice was found, this was only conclusively so for voters of Sinn Féin. The fact that Fine Gael won the election despite campaigning for a policy that was widely unpopular - even amongst its own voters - and that their support for this policy did not appear to lose them first-preference votes to their main electoral competitor in the Labour Party indicates that parties may suggest some unpopular policies without being 
punished electorally for doing so. This may give grounds for parties to incorporate environmental protection policies even if public support for such policies is not present. However, the difficulties in executing the water charges policy once in government and the subsequent reversal of the policy displays the challenge of implementing deeply unpopular policies even when you have a mandate. Such challenges are likely to increase in relevance over the coming years given the growing need for governments worldwide to implement a range of costly environmental policies if they are to meet the ambitious climate change targets that they have set themselves. Therefore, putting in place programmes to boost the environmental dispositions of citizens in advance of implementing costly environmental protection policies may lead to greater success rates for such top-down initiatives.

In conclusion, this paper demonstrates that - even during a period of heightened economic insecurity - the publics' expressed willingness to make personal sacrifices in order to protect the environment is more than an empty or meaningless response, but has important implications for their support of a policy with tangible environmental benefits even when such a policy is largely being framed through an alternative lens and its environmental implications are side-lined in public discourse.

\section{References}

Abou-Chadi, Tarik, and Mark A. Kayser. 2017. 'It's Not Easy Being Green: Why Voters Punish Parties for Environmental Policies during Economic Downturns.” Electoral Studies 45 (February): 201-7.

Anderson, Brilé, Tobias Böhmelt, and Hugh Ward. 2017. "Public Opinion and Environmental Policy Output: A Cross-National Analysis of Energy Policies in Europe." Environmental Research Letters 12 (11).

Anderson, Sarah E. 2011. "Complex Constituencies: Intense Environmentalists and 
Representation.” Environmental Politics 20 (4): 547-65.

Barth, Erling, Henning Finseraas, and Karl O. Moene. 2015. "Political Reinforcement: How Rising Inequality Curbs Manifested Welfare Generosity.” American Journal of Political Science 59 (3): 565-77.

Bean, Clive, and Jonathan Kelley. 1995. "The Electoral Impact of New Politics Issues: The Environment in the 1990 Australian Federal Election." Comparative Politics 27 (3): $339-56$.

Carsey, Thomas M., and Geoffrey C. Layman. 2006. "Changing Sides or Changing Minds? Party Identification and Policy Preferences in the American Electorate.” American Journal of Political Science 50 (2): 464-77.

Daniels, David P., Jon A. Krosnick, Michael P. Tichy, and Trevor Tompson. 2012. "Public Opinion on Environmental Policy in the United States." In The Oxford Handbook of U.S. Environmental Policy, edited by Michael E. Kraft and Sheldon Kamieniecki, 46186. New York: Oxford University Press.

Diamantopoulos, Adamantios, Bodo B. Schlegelmilch, Rudolf R. Sinkovics, and Greg M. Bohlen. 2003. "Can Socio-Demographics Still Play a Role in Profiling Green Consumers? A Review of the Evidence and an Empirical Investigation.” Journal of Business Research 56 (6): 465-80.

Dresner, Simon, Louise Dunne, Peter Clinch, and Christiane Beuermann. 2006. "Social and Political Responses to Ecological Tax Reform in Europe: An Introduction to the Special Issue.” Energy Policy 34 (8): 895-904.

Environmental Protection Agency. 2017. "Urban Waste Water Treatment in 2016." Wexford. 2017. https://www.epa.ie/pubs/reports/water/wastewater/Urban waste water report for 
2016 Final Version.pdf.

Expert Commission on Domestic Public Water Services. 2016. "Report on the Funding of Domestic Public Water Services in Ireland: November 2016.” https://www.oireachtas.ie/parliament/media/committees/futurefundingofdomesticwaters ervices/Report-of-Expert-Commission-on-Domestic-Public-Water-Services.pdf.

Fairbrother, Malcolm. 2013. "Rich People, Poor People, and Environmental Concern:

Evidence across Nations and Time.” European Sociological Review 29 (5): 910-22.

2016. "Trust and Public Support for Environmental Protection in Diverse National

Contexts." Sociological Science 3: 359-82.

—. 2019. "When Will People Pay to Pollute? Environmental Taxes, Political Trust and Experimental Evidence from Britain.” British Journal of Political Science 49 (2): 661 82.

Gallagher, Michael. 2011. "Ireland's Earthquake Election: Analysis of the Results.” In How Ireland Voted 2011: The Full Story of Ireland's Earthquake Election, edited by Michael Gallagher and Michael Marsh, 139-71. London: Palgrave Macmillan.

Green, Jane, and Sara B. Hobolt. 2008. “Owning the Issue Agenda: Party Strategies and Vote Choices in British Elections.” Electoral Studies 27 (3): 460-76.

Hardiman, Niamh, and Muiris MacCarthaigh. 2013. "How Governments Retrench in Crisis: The Case of Ireland." UCD Geary Institute Discussion Paper Series Geary WP20.

Harring, Niklas, and Jacob Sohlberg. 2017. "The Varying Effects of Left-Right Ideology on Support for the Environment: Evidence from a Swedish Survey Experiment.” Environmental Politics 26 (2): 278-300.

Ireland. 2010. "Letter of Intent, Memorandum of Economic and Financial Policies, and 
Technical Memorandum of Understanding.” 2010.

https://www.imf.org/external/np/loi/2010/irl/120310.pdf.

Kallbekken, Steffen, and Marianne Aasen. 2010. "The Demand for Earmarking: Results from a Focus Group Study." Ecological Economics 69 (11): 2183-90.

Kallbekken, Steffen, and Håkon Sæælen. 2011. "Public Acceptance for Environmental Taxes: Self-Interest, Environmental and Distributional Concerns.” Energy Policy 39 (5): $2966-73$

Kenny, John. 2018. “The Role of Economic Perceptions in Influencing Views on Climate Change: An Experimental Analysis with British Respondents." Climate Policy 18 (5): 581-92.

Kollmuss, Anja, and Julian Agyeman. 2002. "Mind the Gap: Why Do People Behave Environmentally and What Are the Barriers to Pro-Environmental Behaviour." Environmental Education Research 8 (3): 239-60.

Leahy, Pat. 2011. “Campaign Strategies and Political Marketing.” In How Ireland Voted 2011: The Full Story of Ireland's Earthquake Election, edited by Michael Gallagher and Michael Marsh, 68-88. Basingstoke: Palgrave Macmillan.

Lenihan, Brian. 2009. "Financial Statement of the Minister for Finance.” Government of Ireland. 2009. http://www.budget.gov.ie/Budgets/2010/FinancialStatement.aspx.

Mair, Peter. 2011. “The Election in Context.” In How Ireland Voted 2011: The Full Story of Ireland's Earthquake Election , edited by Michael Gallagher and Michael Marsh, 28397. London: Palgrave Macmillan.

Marsh, Michael. 2010. "Voting Behaviour." In Politics in the Republic of Ireland (5th Edition), edited by John Coakley and Michael Gallagher, 168-97. Abingdon: Routledge; 
PSAI Press.

Marsh, Michael, David M. Farrell, and Gail McElroy. 2017. “Appendix The INES 2011 Questionnaire.” In A Conservative Revolution?: Electoral Change in Twenty-First Century Ireland, edited by Michael Marsh, David M. Farrell, and Gail McElroy, 22352. Oxford: Oxford University Press.

Marsh, Michael, David M. Farrell, and Theresa Reidy. 2018. "Ireland's Post-Crisis Election." In The Post-Crisis Irish Voter: Voting Behaviour in the Irish 2016 General Election, edited by Michael Marsh, David M. Farrell, and Theresa Reidy, 1-13. Manchester: Manchester Universiity Press.

Marsh, Michael, Richard Sinnott, John Garry, and Fiachra Kennedy. 2008. The Irish Voter: The Nature of Electoral Competition in the Republic of Ireland. Manchester: Manchester Universiity Press.

Martinsson, Johan, and Lennart J. Lundqvist. 2010. "Ecological Citizenship: Coming out ‘clean' without Turning 'Green'?” Environmental Politics 19 (4): 518-37.

Mayer, Adam, and E. Keith Smith. 2017. "Rethinking Economic Conditions and Environmental Attitudes: Macroeconomic Effects, Individual Experiences, and Subjectivity." Social Currents 4 (4): 342-59.

Morris, Dearbháile, Aksana Chyzheuskaya, Diarmuid O’Donovan, Srinivas Raghavendra, Martina Prendergast, and Martin Cormican. 2016. "Economic Assessment of the Waterborne Outbreak of Cryptosporidium Hominis in Galway, 2007.” Environmental Protection Agency. Wexford. 2016. http://www.epa.ie/pubs/reports/research/water/EPA - Research Report 177_Essentra web.pdf.

OECD. 2003. Social Issues in the Provision and Pricing of Water Services. Paris: OECD. 
- 2009. Managing Water for All: An OECD Perspective on Pricing and Financing. Organisation for Economic Co-Operation and Development. Paris: OECD.

Reidy, Theresa, Jane Suiter, and Michael Breen. 2018. "Boom and Bust: Economic Voting in Ireland." Politics 38 (2): 148-64.

Scott, Susan. 2003. "Abolition of Domestic Water Charges in Ireland.” Economic and Social Research Institute. 2003. http://www.esri.ie/pubs/JACB200850.pdf.

Singer, Matthew M. 2011. "Who Says 'It's the Economy'? Cross-National and CrossIndividual Variance in the Salience of Economic Performance." Comparative Political Studies 44 (3): 284-312.

Tilley, James, and John Garry. 2017. "Class Politics in Ireland: How Economic Catastrophe Realigned Irish Politics along Economic Divisions." In A Conservative Revolution?: Electoral Change in Twenty-First Century Ireland, edited by Michael Marsh, David M. Farrell, and Gail McElroy, 11-27. Oxford: Oxford University Press.

Torgler, Benno, and María A. García-Valiñas. 2007. "The Determinants of Individuals' Attitudes towards Preventing Environmental Damage." Ecological Economics 63 (2-3): $536-52$.

Van Der Eijk, Cees, Wouter Van Der Brug, Martin Kroh, and Mark Franklin. 2006. "Rethinking the Dependent Variable in Voting Behavior: On the Measurement and Analysis of Electoral Utilities.” Electoral Studies 25 (3): 424-47.

Van Liere, Kent D., and Riley E. Dunlap. 1980. "The Social Bases of Environmental Concern: A Review of Hypotheses, Explanations and Empirical Evidence.” Public Opinion Quarterly 44 (2): 181-97.

Weeks, Liam. 2010. "Parties and the Party System." In Politics in the Republic of Ireland 
(5th Edition), edited by John Coakley and Michael Gallagher, 137-67. Abingdon:

Routledge; PSAI Press.

Zelezny, Lynnette C, Poh-Pheng Chua, and Christina Aldrich. 2000. "Elaborating on Gender Differences in Environmentalism.” Journal of Social Issues 56 (3): 443-57.

Zhao, Y.Q., and D. Crosbie. 2012. "Water Pricing in Ireland: A Techno-Economic and Political Assessment.” International Journal of Environmental Studies 69 (3): 427-42. 
Environmentalism undercover: The environmental dimension of public support for domestic water charges

\section{Online Appendix}

Table A1: Logistic Regression of Support for Water Charges with Party Closeness - Full Models

\begin{tabular}{|c|c|c|c|c|c|c|}
\hline \multirow[b]{2}{*}{ VARIABLES } & \multicolumn{2}{|c|}{ (1) } & \multicolumn{2}{|c|}{ (2) } & \multicolumn{2}{|c|}{ (3) } \\
\hline & Coef & $\mathrm{Se}$ & Coef & $\mathrm{Se}$ & Coef & $\mathrm{se}$ \\
\hline Env Standard of Living & $0.27 * * *$ & $(0.04)$ & & & & \\
\hline Env Higher Taxes & & & $0.11^{* * *}$ & $(0.03)$ & & \\
\hline Economy v. Environment & & & & & 0.03 & $(0.02)$ \\
\hline \multicolumn{7}{|l|}{ Party Close (FG) } \\
\hline FF & 0.32 & $(0.24)$ & 0.34 & $(0.22)$ & 0.32 & $(0.22)$ \\
\hline Labour & -0.47 & $(0.29)$ & -0.36 & $(0.26)$ & -0.42 & $(0.28)$ \\
\hline SF & $-0.92 * *$ & $(0.38)$ & $-1.04 * * *$ & $(0.36)$ & $-1.06 * * *$ & $(0.38)$ \\
\hline Other/None & -0.21 & $(0.17)$ & $-0.27 *$ & $(0.16)$ & $-0.30 *$ & $(0.19)$ \\
\hline \multicolumn{7}{|l|}{ Income $(<€ 20,000)$} \\
\hline$€ 20,000-24,999$ & 0.27 & $(0.28)$ & 0.36 & $(0.27)$ & 0.37 & $(0.27)$ \\
\hline$€ 25,000-29,999$ & 0.04 & $(0.31)$ & 0.21 & $(0.29)$ & 0.21 & $(0.29)$ \\
\hline$€ 30,000-34,999$ & 0.11 & $(0.28)$ & 0.07 & $(0.26)$ & 0.08 & $(0.26)$ \\
\hline$€ 35,000-39,999$ & 0.33 & $(0.32)$ & 0.35 & $(0.30)$ & 0.44 & $(0.29)$ \\
\hline$€ 40,000-49,999$ & $0.66 * *$ & $(0.28)$ & $0.82 * * *$ & $(0.26)$ & $0.78 * * *$ & $(0.26)$ \\
\hline$€ 50,000-69,999$ & $0.59 * *$ & $(0.27)$ & $0.80 * * *$ & $(0.25)$ & $0.79 * * *$ & $(0.25)$ \\
\hline$>€ 70,000$ & $0.83 * *$ & $(0.36)$ & $0.87 * * *$ & $(0.33)$ & $0.84 * *$ & $(0.33)$ \\
\hline Refused to answer & $0.44 * *$ & $(0.21)$ & $0.58 * * *$ & $(0.19)$ & $0.58 * * *$ & $(0.19)$ \\
\hline \multicolumn{7}{|l|}{ Unemployed } \\
\hline Full Time Employed & 0.31 & $(0.25)$ & 0.37 & $(0.24)$ & 0.38 & $(0.23)$ \\
\hline Part Time Employed & $0.52 *$ & $(0.28)$ & $0.56^{* *}$ & $(0.26)$ & $0.56^{* *}$ & $(0.26)$ \\
\hline Student & 0.23 & $(0.35)$ & 0.29 & $(0.34)$ & 0.33 & $(0.34)$ \\
\hline Retired & 0.44 & $(0.33)$ & 0.46 & $(0.30)$ & 0.46 & $(0.30)$ \\
\hline House Duties & 0.41 & $(0.30)$ & 0.44 & $(0.28)$ & 0.43 & $(0.28)$ \\
\hline \multicolumn{7}{|l|}{ House Owner/No Mortgage } \\
\hline Owner with loan/mortgage & $-0.29 *$ & $(0.15)$ & $-0.30 * *$ & $(0.14)$ & $-0.28 * *$ & $(0.14)$ \\
\hline Local Authority Tenant & $-0.65^{* *}$ & $(0.30)$ & $-0.65^{* *}$ & $(0.28)$ & $-0.67 * *$ & $(0.27)$ \\
\hline Private Tenant & 0.26 & $(0.24)$ & 0.27 & $(0.22)$ & 0.29 & $(0.23)$ \\
\hline Other & -0.12 & $(0.53)$ & -0.15 & $(0.48)$ & -0.18 & $(0.50)$ \\
\hline Tax v. Spending & $0.08 * *$ & $(0.03)$ & $0.06^{* *}$ & $(0.03)$ & $0.07 * *$ & $(0.03)$ \\
\hline Age & $0.01 * *$ & $(0.01)$ & $0.01 * *$ & $(0.01)$ & $0.01 * *$ & $(0.01)$ \\
\hline Female & $-0.36 * * *$ & $(0.14)$ & $-0.27 * *$ & $(0.13)$ & $-0.27 * *$ & $(0.13)$ \\
\hline \multicolumn{7}{|l|}{ Education (primary) } \\
\hline Junior Certificate & 0.22 & $(0.30)$ & 0.11 & $(0.28)$ & 0.09 & $(0.27)$ \\
\hline Leaving Certificate & $0.67 * *$ & $(0.29)$ & $0.46^{*}$ & $(0.27)$ & $0.46^{*}$ & $(0.26)$ \\
\hline Diploma/Certificate & $0.94 * * *$ & $(0.31)$ & $0.72 * *$ & $(0.28)$ & $0.73 * * *$ & $(0.28)$ \\
\hline University & $1.13^{* * *}$ & $(0.32)$ & $1.07 * * *$ & $(0.29)$ & $1.09 * * *$ & $(0.29)$ \\
\hline
\end{tabular}


Political Interest (Not at all)

\begin{tabular}{|c|c|c|c|c|c|c|}
\hline Not Very & 0.34 & $(0.28)$ & 0.42 & $(0.26)$ & 0.39 & $(0.26)$ \\
\hline Quite Interested & $0.76^{* * *}$ & $(0.26)$ & $0.86^{* * *}$ & $(0.25)$ & $0.86^{* * *}$ & $(0.24)$ \\
\hline Very Interested & $0.88 * * *$ & $(0.30)$ & $1.00 * * *$ & $(0.28)$ & $1.00 * * *$ & $(0.28)$ \\
\hline Days listen to national radio per week & $0.09 * * *$ & $(0.03)$ & $0.07 * * *$ & $(0.03)$ & $0.08 * * *$ & $(0.03)$ \\
\hline Constant & $-4.44 * * *$ & $(0.61)$ & $-3.83 * * *$ & $(0.56)$ & $-3.73 * * *$ & $(0.56)$ \\
\hline Pseudo $\mathrm{R}^{2}$ & \multirow{2}{*}{\multicolumn{2}{|c|}{0.15}} & \multicolumn{2}{|c|}{0.13} & \multicolumn{2}{|c|}{0.12} \\
\hline Observations & & & \multicolumn{2}{|c|}{1,738} & \multicolumn{2}{|c|}{1,743} \\
\hline
\end{tabular}

Robust standard errors in parentheses

$* * * \mathrm{p}<0.01, * * \mathrm{p}<0.05, * \mathrm{p}<0.1$ 
Table A2: Logistic Regression of Support for Water Charges with 2011 Vote/Vote Intention

\begin{tabular}{|c|c|c|c|c|c|c|}
\hline \multirow[b]{2}{*}{ VARIABLES } & \multirow[b]{2}{*}{ Coef } & \multirow{2}{*}{$\begin{array}{l}\text { (1) } \\
\text { se }\end{array}$} & \multicolumn{2}{|c|}{ (2) } & \multicolumn{2}{|c|}{ (3) } \\
\hline & & & Coef & se & Coef & se \\
\hline Env Standard of Living & $0.26 * * *$ & $(0.04)$ & & & & \\
\hline Env Higher Taxes & & & $0.12 * * *$ & $(0.03)$ & & \\
\hline Economy v. Environment & & & & & 0.03 & $(0.02)$ \\
\hline 2011 Vote (FG) & & & & & & \\
\hline $\mathrm{FF}$ & 0.07 & $(0.18)$ & 0.10 & $(0.17)$ & 0.08 & $(0.16)$ \\
\hline LAB & $-0.44 * * *$ & $(0.17)$ & $-0.35^{* *}$ & $(0.16)$ & $-0.37 * *$ & $(0.16)$ \\
\hline SF & $-1.10 * * *$ & $(0.28)$ & $-1.26 * * *$ & $(0.26)$ & $-1.25 * * *$ & $(0.26)$ \\
\hline IND & -0.16 & $(0.21)$ & -0.20 & $(0.20)$ & -0.20 & $(0.20)$ \\
\hline Other & -0.09 & $(0.31)$ & -0.03 & $(0.29)$ & -0.02 & $(0.29)$ \\
\hline Refused/Don’t Know & -0.23 & $(0.31)$ & -0.16 & $(0.28)$ & -0.26 & $(0.27)$ \\
\hline Income $(<€ 20,000)$ & & & & & & \\
\hline$€ 20,000-24,999$ & 0.19 & $(0.28)$ & 0.30 & $(0.27)$ & 0.30 & $(0.27)$ \\
\hline$€ 25,000-29,999$ & 0.01 & $(0.31)$ & 0.18 & $(0.29)$ & 0.18 & $(0.29)$ \\
\hline$€ 30,000-34,999$ & 0.05 & $(0.29)$ & 0.03 & $(0.27)$ & 0.04 & $(0.27)$ \\
\hline$€ 35,000-39,999$ & 0.28 & $(0.32)$ & 0.32 & $(0.30)$ & 0.40 & $(0.29)$ \\
\hline$€ 40,000-49,999$ & $0.57 * *$ & $(0.29)$ & $0.74 * * *$ & $(0.27)$ & $0.71 * * *$ & $(0.27)$ \\
\hline$€ 50,000-69,999$ & $0.53^{*}$ & $(0.27)$ & $0.75^{* * *}$ & $(0.25)$ & $0.73 * * *$ & $(0.25)$ \\
\hline$>€ 70,000$ & $0.73 * *$ & $(0.37)$ & $0.79 * *$ & $(0.33)$ & $0.76 * *$ & $(0.33)$ \\
\hline Refused to answer & $0.40^{*}$ & $(0.21)$ & $0.55 * * *$ & $(0.20)$ & $0.55^{* * *}$ & $(0.20)$ \\
\hline Unemployed & & & & & & \\
\hline Full Time Employed & 0.31 & $(0.25)$ & 0.33 & $(0.24)$ & 0.35 & $(0.23)$ \\
\hline Part Time Employed & $0.52 *$ & $(0.28)$ & $0.56 * *$ & $(0.26)$ & $0.55^{* *}$ & $(0.26)$ \\
\hline Student & 0.26 & $(0.36)$ & 0.32 & $(0.34)$ & 0.36 & $(0.34)$ \\
\hline Retired & 0.48 & $(0.33)$ & 0.47 & $(0.30)$ & 0.47 & $(0.30)$ \\
\hline House Duties & 0.39 & $(0.29)$ & 0.39 & $(0.28)$ & 0.38 & $(0.28)$ \\
\hline House Owner/No Mortgage & & & & & & \\
\hline wner with loan/mortgage & $-0.29 *$ & $(0.15)$ & $-0.29 * *$ & $(0.14)$ & $-0.27 *$ & $(0.14)$ \\
\hline Local Authority Tenant & $-0.59 *$ & $(0.30)$ & $-0.59 * *$ & $(0.28)$ & $-0.60 * *$ & $(0.28)$ \\
\hline Private Tenant & 0.26 & $(0.24)$ & 0.28 & $(0.23)$ & 0.29 & $(0.23)$ \\
\hline Other & -0.13 & $(0.53)$ & -0.17 & $(0.48)$ & -0.19 & $(0.49)$ \\
\hline Tax v. Spending & $0.07 * *$ & $(0.03)$ & $0.06 * *$ & $(0.03)$ & $0.07 * *$ & $(0.03)$ \\
\hline Age & $0.01 * *$ & $(0.01)$ & $0.01 * *$ & $(0.01)$ & $0.01 * *$ & $(0.01)$ \\
\hline Females & $-0.36 * * *$ & $(0.14)$ & $-0.28 * *$ & $(0.13)$ & $-0.27 * *$ & $(0.13)$ \\
\hline Education (primary) & & & & & & \\
\hline Junior Certificate & 0.29 & $(0.30)$ & 0.19 & $(0.27)$ & 0.18 & $(0.27)$ \\
\hline Leaving Certificate & $0.70 * *$ & $(0.29)$ & $0.50 *$ & $(0.26)$ & $0.50 *$ & $(0.26)$ \\
\hline Diploma/Certificate & $0.96^{* * *}$ & $(0.30)$ & $0.74 * * *$ & $(0.28)$ & $0.75^{* * *}$ & $(0.28)$ \\
\hline University & $1.14 * * *$ & $(0.31)$ & $1.09 * * *$ & $(0.29)$ & $1.12 * * *$ & $(0.28)$ \\
\hline $\begin{array}{l}\text { Political Interest (Not at al } \\
\text { Not Very }\end{array}$ & 0.31 & $(0.28)$ & 0.40 & $(0.26)$ & 0.38 & $(0.26)$ \\
\hline
\end{tabular}




\begin{tabular}{|c|c|c|c|c|c|c|}
\hline Quite Interested & $0.74 * * *$ & $(0.26)$ & $0.84 * * *$ & $(0.25)$ & $0.85 * * *$ & $(0.24)$ \\
\hline Very Interested & $0.92 * * *$ & $(0.29)$ & $1.06^{* * *}$ & $(0.28)$ & $1.07 * * *$ & $(0.28)$ \\
\hline Days listen to national radio per week & $0.10^{* * *}$ & $(0.03)$ & $0.08 * * *$ & $(0.03)$ & $0.09 * * *$ & $(0.03)$ \\
\hline Constant & $-4.39 * * *$ & $(0.59)$ & $-3.86 * * *$ & $(0.54)$ & $-3.76 * * *$ & $(0.54)$ \\
\hline Psuedo $\mathrm{R}^{2}$ & \multirow{2}{*}{\multicolumn{2}{|c|}{$\begin{array}{c}0.15 \\
1563\end{array}$}} & \multicolumn{2}{|c|}{$\begin{array}{c}0.13 \\
1738\end{array}$} & \multicolumn{2}{|c|}{0.13} \\
\hline Observations & & 1,563 & \multicolumn{2}{|c|}{1,738} & \multicolumn{2}{|c|}{1,743} \\
\hline
\end{tabular}

Robust standard errors in parentheses $* * * \mathrm{p}<0.01, * * \mathrm{p}<0.05, * \mathrm{p}<0.1$ 
Table A3: Logistic Regression of Support for Water Charges with Probability to Ever Vote for a Party

\begin{tabular}{|c|c|c|c|c|c|c|}
\hline \multirow[b]{2}{*}{ VARIABLES } & \multicolumn{2}{|c|}{ (1) } & \multicolumn{2}{|c|}{ (2) } & \multicolumn{2}{|c|}{ (3) } \\
\hline & Coef & se & Coef & se & Coef & se \\
\hline Env Standard of Living & $0.27 * * *$ & $(0.04)$ & & & & \\
\hline Env Higher Taxes & & & $0.12 * * *$ & $(0.03)$ & & \\
\hline Economy v. Environment & & & & & 0.03 & $(0.02)$ \\
\hline Prob FF & $0.06^{* * *}$ & $(0.02)$ & $0.05^{* *}$ & $(0.02)$ & $0.05^{* * *}$ & $(0.02)$ \\
\hline Prob FG & $0.05^{* *}$ & $(0.02)$ & $0.04 *$ & $(0.02)$ & $0.04 *$ & $(0.02)$ \\
\hline Prob Green & $0.07 * *$ & $(0.03)$ & $0.09 * * *$ & $(0.03)$ & $0.10 * * *$ & $(0.03)$ \\
\hline Prob Labour & $-0.05^{*}$ & $(0.03)$ & $-0.04 *$ & $(0.02)$ & $-0.04 *$ & $(0.02)$ \\
\hline Prob SF & $-0.08 * * *$ & $(0.02)$ & $-0.10 * * *$ & $(0.02)$ & $-0.10 * * *$ & $(0.02)$ \\
\hline Prob IND & -0.01 & $(0.02)$ & -0.02 & $(0.02)$ & -0.03 & $(0.02)$ \\
\hline Prob ULA & $-0.12 * * *$ & $(0.03)$ & $-0.11 * * *$ & $(0.03)$ & $-0.11 * * *$ & $(0.03)$ \\
\hline \multicolumn{7}{|l|}{ Income $(<€ 20,000)$} \\
\hline$€ 20,000-24,999$ & 0.20 & $(0.28)$ & 0.30 & $(0.28)$ & 0.30 & $(0.28)$ \\
\hline$€ 25,000-29,999$ & -0.02 & $(0.31)$ & 0.13 & $(0.29)$ & 0.12 & $(0.29)$ \\
\hline$€ 30,000-34,999$ & 0.01 & $(0.29)$ & 0.02 & $(0.27)$ & 0.02 & $(0.27)$ \\
\hline$€ 35,000-39,999$ & 0.25 & $(0.33)$ & 0.31 & $(0.31)$ & 0.38 & $(0.31)$ \\
\hline$€ 40,000-49,999$ & $0.60 * *$ & $(0.28)$ & $0.73 * * *$ & $(0.27)$ & $0.69 * *$ & $(0.27)$ \\
\hline$€ 50,000-69,999$ & $0.49^{*}$ & $(0.27)$ & $0.69 * * *$ & $(0.26)$ & $0.67 * * *$ & $(0.26)$ \\
\hline$>€ 70,000$ & 0.57 & $(0.37)$ & $0.61 *$ & $(0.34)$ & $0.57 *$ & $(0.34)$ \\
\hline Refused to answer & $0.38 *$ & $(0.21)$ & $0.52 * * *$ & $(0.20)$ & $0.51 * * *$ & $(0.20)$ \\
\hline \multicolumn{7}{|l|}{ Unemployed } \\
\hline Full Time Employed & 0.13 & $(0.26)$ & 0.17 & $(0.24)$ & 0.20 & $(0.24)$ \\
\hline Part Time Employed & 0.37 & $(0.28)$ & 0.41 & $(0.27)$ & 0.43 & $(0.27)$ \\
\hline Student & 0.14 & $(0.37)$ & 0.20 & $(0.35)$ & 0.27 & $(0.35)$ \\
\hline Retired & 0.29 & $(0.34)$ & 0.31 & $(0.31)$ & 0.32 & $(0.31)$ \\
\hline House Duties & 0.25 & $(0.30)$ & 0.25 & $(0.29)$ & 0.25 & $(0.29)$ \\
\hline \multicolumn{7}{|l|}{ House Owner/No Mortgage } \\
\hline Owner with loan/mortgage & -0.25 & $(0.15)$ & $-0.25^{*}$ & $(0.15)$ & -0.23 & $(0.15)$ \\
\hline Local Authority Tenant & $-0.56^{*}$ & $(0.31)$ & $-0.58 * *$ & $(0.29)$ & $-0.59 * *$ & $(0.29)$ \\
\hline Private Tenant & 0.33 & $(0.25)$ & 0.32 & $(0.23)$ & 0.32 & $(0.23)$ \\
\hline Other & -0.16 & $(0.57)$ & -0.23 & $(0.53)$ & -0.27 & $(0.55)$ \\
\hline Tax v. Spending & $0.09 * * *$ & $(0.03)$ & $0.07 * * *$ & $(0.03)$ & $0.08 * * *$ & $(0.03)$ \\
\hline Age & $0.01 * *$ & $(0.01)$ & $0.01 * *$ & $(0.01)$ & $0.01 * *$ & $(0.01)$ \\
\hline Females & $-0.42 * * *$ & $(0.14)$ & $-0.35 * * *$ & $(0.13)$ & $-0.34 * * *$ & $(0.13)$ \\
\hline \multicolumn{7}{|l|}{ Education (primary) } \\
\hline Junior Certificate & 0.25 & $(0.30)$ & 0.17 & $(0.28)$ & 0.15 & $(0.28)$ \\
\hline Leaving Certificate & $0.72 * *$ & $(0.29)$ & $0.52 * *$ & $(0.27)$ & $0.52 * *$ & $(0.26)$ \\
\hline Diploma/Certificate & $1.05^{* * *}$ & $(0.31)$ & $0.82 * * *$ & $(0.28)$ & $0.82 * * *$ & $(0.28)$ \\
\hline University & $1.23 * * *$ & $(0.32)$ & $1.15 * * *$ & $(0.29)$ & $1.17 * * *$ & $(0.29)$ \\
\hline \multicolumn{7}{|l|}{ Political Interest (Not at all) } \\
\hline Not Very & 0.30 & $(0.28)$ & 0.41 & $(0.26)$ & 0.39 & $(0.26)$ \\
\hline
\end{tabular}




\begin{tabular}{|c|c|c|c|c|c|c|}
\hline Quite Interested & $0.71 * * *$ & $(0.26)$ & $0.83 * * *$ & $(0.25)$ & $0.84 * * *$ & $(0.25)$ \\
\hline Very Interested & $0.90 * * *$ & $(0.30)$ & $1.04 * * *$ & $(0.29)$ & $1.06 * * *$ & $(0.28)$ \\
\hline Days listen to national radio per week & $0.10 * * *$ & $(0.03)$ & $0.08 * * *$ & $(0.03)$ & $0.09 * * *$ & $(0.03)$ \\
\hline Constant & $-4.46 * * *$ & $(0.65)$ & $-3.73 * * *$ & $(0.59)$ & $-3.69 * * *$ & $(0.59)$ \\
\hline Observations & \multicolumn{2}{|c|}{$\begin{array}{c}0.17 \\
1,563\end{array}$} & \multicolumn{2}{|c|}{0.15} & \multicolumn{2}{|c|}{0.15} \\
\hline
\end{tabular}

Robust standard errors in parentheses

$* * * \mathrm{p}<0.01, * * \mathrm{p}<0.05, * \mathrm{p}<0.1$ 
Table A4: Logistic Regression of Support for Water Charges with Interactions

\begin{tabular}{lcccccc}
\hline & \multicolumn{2}{c}{$(1)$} & \multicolumn{2}{c}{$(2)$} & & \\
VARIABLES & Coef & se & Coef & se & Coef & se \\
\hline & & & & & & \\
Env Standard of Living & 0.12 & $(0.09)$ & & & & \\
$\begin{array}{l}\text { Env Higher Taxes } \\
\text { Economy v. Environment }\end{array}$ & & & 0.08 & $(0.08)$ & & \\
& & & & & -0.07 & $(0.06)$ \\
Party Close (FG) & & & & & & \\
FF & 0.50 & $(0.54)$ & 0.51 & $(0.48)$ & -0.34 & $(0.49)$ \\
Labour & $-2.31^{* * *}$ & $(0.82)$ & $-1.60^{* * *}$ & $(0.73)$ & $-1.42^{* * *}$ & $(0.65)$ \\
SF & -0.65 & $(0.75)$ & -0.22 & $(0.63)$ & -0.95 & $(0.75)$ \\
Other/None & $-0.98^{* * *}$ & $(0.39)$ & $-0.44^{* *}$ & $(0.35)$ & $-0.90^{* * *}$ & $(0.37)$
\end{tabular}

Party Close $(\mathrm{FG}) *$ Env SoL

FF

Labour

SF

Other/None

Party Close $(\mathrm{FG}) *$ Env Tax

$\mathrm{FF}$

Labour

$\mathrm{SF}$

Other/None

Party Close (FG)*Env Econ

FF

Labour

SF

Other/None

Income $(<€ 20,000)$

$€ 20,000-24,999$

$€ 25,000-29,999$

$€ 30,000-34,999$

$€ 35,000-39,999$

$€ 40,000-49,999$

$€ 50,000-69,999$

$>€ 70,000$

Refused to answer

Unemployed

Full Time Employed

Part Time Employed

Student

Retired

House Duties

House Owner/No Mortgage

Owner with loan/mortgage

Local Authority Tenant

Private Tenant

$\begin{array}{cc}-0.06 & (0.14) \\ 0.50 * * & (0.21) \\ -0.08 & (0.20) \\ 0.22 * * & (0.10)\end{array}$

$$
\begin{array}{cc}
-0.06 & (0.13) \\
0.34 * * & (0.18) \\
-0.25 & (0.16) \\
0.05 & (0.09)
\end{array}
$$

$0.13 \quad(0.09)$

$0.19 * \quad(0.10)$

$-0.02 \quad(0.13)$

$0.11^{*} \quad(0.06)$

$\begin{array}{cccccc}0.25 & (0.28) & 0.36 & (0.27) & 0.39 & (0.27) \\ 0.01 & (0.31) & 0.21 & (0.29) & 0.21 & (0.29) \\ 0.08 & (0.29) & 0.07 & (0.27) & 0.10 & (0.26) \\ 0.25 & (0.32) & 0.34 & (0.30) & 0.44 & (0.29) \\ 0.61 * * & (0.28) & 0.82^{* * *} & (0.27) & 0.79 * * * & (0.26) \\ 0.54 * * & (0.27) & 0.80^{* * *} & (0.25) & 0.79 * * * & (0.25) \\ 0.82^{* *} & (0.36) & 0.84 * * & (0.33) & 0.82 * * & (0.33) \\ 0.41^{* *} & (0.21) & 0.57 * * * & (0.20) & 0.57 * * * & (0.19)\end{array}$

$\begin{array}{cccccc}0.35 & (0.25) & 0.39 & (0.24) & 0.36 & (0.23) \\ 0.58^{* *} & (0.28) & 0.57 * * & (0.26) & 0.55^{* *} & (0.26) \\ 0.27 & (0.36) & 0.28 & (0.34) & 0.34 & (0.34) \\ 0.47 & (0.33) & 0.47 & (0.31) & 0.44 & (0.30) \\ 0.43 & (0.30) & 0.44 & (0.28) & 0.41 & (0.28)\end{array}$

$\begin{array}{cccccc}-0.29 * & (0.15) & -0.30 * * & (0.14) & -0.29 * * & (0.14) \\ -0.65 * * & (0.30) & -0.62 * * & (0.28) & -0.71 * * * & (0.27) \\ 0.27 & (0.24) & 0.27 & (0.23) & 0.28 & (0.23)\end{array}$




\begin{tabular}{|c|c|c|c|c|c|c|}
\hline Other & -0.20 & $(0.55)$ & -0.20 & $(0.49)$ & -0.20 & $(0.50)$ \\
\hline Tax v. Spending & $0.08 * *$ & $(0.03)$ & $0.06^{* *}$ & $(0.03)$ & $0.07 * *$ & $(0.03)$ \\
\hline Age & $0.01 * *$ & $(0.01)$ & $0.01 * *$ & $(0.01)$ & $0.01 * *$ & $(0.01)$ \\
\hline Females & $-0.35^{* *}$ & $(0.14)$ & $-0.28 * *$ & $(0.13)$ & $-0.25^{*}$ & $(0.13)$ \\
\hline \multicolumn{7}{|l|}{ Education (primary) } \\
\hline Junior Certificate & 0.25 & $(0.30)$ & 0.12 & $(0.28)$ & 0.09 & $(0.27)$ \\
\hline Leaving Certificate & $0.67 * *$ & $(0.29)$ & $0.48^{*}$ & $(0.27)$ & $0.45^{*}$ & $(0.26)$ \\
\hline Diploma/Certificate & $0.96^{* * *}$ & $(0.31)$ & $0.74 * * *$ & $(0.28)$ & $0.72 * * *$ & $(0.28)$ \\
\hline University & $1.15^{* * *}$ & $(0.32)$ & $1.09 * * *$ & $(0.29)$ & $1.09 * * *$ & $(0.29)$ \\
\hline \multicolumn{7}{|l|}{ Political Interest (Not at all) } \\
\hline Not Very & 0.38 & $(0.28)$ & 0.41 & $(0.26)$ & 0.38 & $(0.26)$ \\
\hline Quite Interested & $0.76^{* * *}$ & $(0.26)$ & $0.84 * * *$ & $(0.25)$ & $0.85^{* * *}$ & $(0.24)$ \\
\hline Very Interested & $0.88 * * *$ & $(0.29)$ & $0.98 * * *$ & $(0.28)$ & $1.00 * * *$ & $(0.28)$ \\
\hline Days listen to national radio per week & $0.09 * * *$ & $(0.03)$ & $0.07 * * *$ & $(0.03)$ & $0.08 * * *$ & $(0.03)$ \\
\hline Constant & $-3.92 * * *$ & $(0.67)$ & $-3.78 * * *$ & $(0.62)$ & $-3.17 * * *$ & $(0.63)$ \\
\hline Pseudo-R ${ }^{2}$ & \multicolumn{2}{|c|}{0.15} & \multicolumn{2}{|c|}{0.13} & \multicolumn{2}{|c|}{0.12} \\
\hline Observations & \multicolumn{2}{|c|}{1,563} & \multicolumn{2}{|c|}{1,738} & \multicolumn{2}{|c|}{1,743} \\
\hline
\end{tabular}

Robust standard errors in parentheses

$* * * \mathrm{p}<0.01, * * \mathrm{p}<0.05, * \mathrm{p}<0.1$ 


\begin{tabular}{|c|c|c|c|c|c|c|}
\hline \multirow[b]{2}{*}{ VARIABLES } & \multicolumn{2}{|r|}{ (1) } & \multicolumn{2}{|c|}{ (2) } & \multicolumn{2}{|c|}{ (3) } \\
\hline & Coef & se & Coef & se & Coef & se \\
\hline Env Standard of Living & 0.06 & $(0.05)$ & & & & \\
\hline Env Higher Taxes & & & 0.04 & $(0.05)$ & & \\
\hline Economy v. Environment & & & & & 0.02 & $(0.03)$ \\
\hline \multicolumn{7}{|l|}{ Party Close (FG) } \\
\hline $\mathrm{FF}$ & $0.54 *$ & $(0.29)$ & $0.52 *$ & $(0.27)$ & 0.52 & $(0.27)$ \\
\hline Labour & -0.41 & $(0.40)$ & -0.40 & $(0.38)$ & -0.43 & $(0.38)$ \\
\hline SF & 0.32 & $(0.40)$ & 0.28 & $(0.38)$ & 0.27 & $(0.38)$ \\
\hline Other/None & 0.01 & $(0.23)$ & -0.07 & $(0.22)$ & -0.08 & $(0.22)$ \\
\hline \multicolumn{7}{|l|}{ Income $(<€ 20,000)$} \\
\hline$€ 20,000-24,999$ & -0.40 & $(0.40)$ & -0.30 & $(0.39)$ & -0.31 & $(0.39)$ \\
\hline$€ 25,000-29,999$ & -0.40 & $(0.39)$ & -0.13 & $(0.38)$ & -0.12 & $(0.38)$ \\
\hline$€ 30,000-34,999$ & -0.23 & $(0.37)$ & 0.01 & $(0.34)$ & 0.02 & $(0.34)$ \\
\hline$€ 35,000-39,999$ & -0.32 & $(0.41)$ & -0.39 & $(0.42)$ & -0.27 & $(0.40)$ \\
\hline$€ 40,000-49,999$ & -0.19 & $(0.37)$ & 0.03 & $(0.35)$ & 0.03 & $(0.35)$ \\
\hline$€ 50,000-69,999$ & 0.02 & $(0.33)$ & 0.25 & $(0.32)$ & 0.25 & $(0.32)$ \\
\hline$>€ 70,000$ & -0.04 & $(0.43)$ & 0.16 & $(0.41)$ & 0.17 & $(0.41)$ \\
\hline Refused to answer & 0.05 & $(0.25)$ & 0.23 & $(0.23)$ & 0.25 & $(0.23)$ \\
\hline \multicolumn{7}{|l|}{ Unemployed } \\
\hline Full Time Employed & -0.01 & $(0.32)$ & -0.28 & $(0.28)$ & -0.27 & $(0.28)$ \\
\hline Part Time Employed & 0.09 & $(0.35)$ & -0.15 & $(0.32)$ & -0.12 & $(0.31)$ \\
\hline Student & -0.19 & $(0.52)$ & -0.66 & $(0.50)$ & -0.65 & $(0.50)$ \\
\hline Retired & -0.32 & $(0.42)$ & -0.45 & $(0.38)$ & -0.45 & $(0.37)$ \\
\hline House Duties & -0.11 & $(0.41)$ & -0.20 & $(0.37)$ & -0.20 & $(0.36)$ \\
\hline \multicolumn{7}{|l|}{ House Owner/No Mortgage } \\
\hline Owner with loan/mortgage & $-0.36^{*}$ & $(0.21)$ & $-0.35^{*}$ & $(0.20)$ & $-0.34 *$ & $(0.20)$ \\
\hline Local Authority Tenant & -0.09 & $(0.37)$ & -0.16 & $(0.35)$ & -0.17 & $(0.35)$ \\
\hline Private Tenant & 0.10 & $(0.33)$ & -0.01 & $(0.32)$ & -0.00 & $(0.32)$ \\
\hline Other & -0.96 & $(0.98)$ & -0.09 & $(0.63)$ & -0.10 & $(0.64)$ \\
\hline Tax v. Spending & 0.05 & $(0.04)$ & 0.03 & $(0.04)$ & 0.04 & $(0.03)$ \\
\hline Age & $0.02 * * *$ & $(0.01)$ & $0.02 * *$ & $(0.01)$ & $0.02 * * *$ & $(0.01)$ \\
\hline Females & -0.17 & $(0.18)$ & -0.15 & $(0.17)$ & -0.15 & $(0.17)$ \\
\hline \multicolumn{7}{|l|}{ Education (primary) } \\
\hline Junior Certificate & -0.21 & $(0.37)$ & -0.13 & $(0.34)$ & -0.12 & $(0.34)$ \\
\hline Leaving Certificate & 0.25 & $(0.35)$ & 0.11 & $(0.32)$ & 0.12 & $(0.32)$ \\
\hline Diploma/Certificate & 0.18 & $(0.37)$ & 0.14 & $(0.35)$ & 0.18 & $(0.35)$ \\
\hline University & $0.82 * *$ & $(0.37)$ & $0.80 * *$ & $(0.34)$ & $0.83 * *$ & $(0.34)$ \\
\hline \multicolumn{7}{|l|}{ Political Interest (Not at all) } \\
\hline Not Very & 0.27 & $(0.36)$ & 0.53 & $(0.35)$ & 0.44 & $(0.34)$ \\
\hline Quite Interested & 0.44 & $(0.35)$ & $0.59 *$ & $(0.34)$ & 0.51 & $(0.33)$ \\
\hline Very Interested & 0.49 & $(0.39)$ & $0.66^{*}$ & $(0.38)$ & 0.59 & $(0.37)$ \\
\hline DK/No Reply & 1.28 & $(1.24)$ & 1.22 & $(1.19)$ & 1.06 & $(1.20)$ \\
\hline Days listen to national radio per week & $0.07 *$ & $(0.04)$ & 0.04 & $(0.04)$ & 0.05 & $(0.04)$ \\
\hline Constant & $-4.06 * * *$ & $(0.75)$ & $-3.54 * * *$ & $(0.69)$ & $-3.56 * * *$ & $(0.71)$ \\
\hline Psuedo $\mathrm{R}^{2}$ & \multicolumn{2}{|c|}{0.07} & \multicolumn{2}{|c|}{0.06} & \multicolumn{2}{|c|}{0.06} \\
\hline Observations & \multicolumn{2}{|c|}{1,452} & \multicolumn{2}{|c|}{1,620} & \multicolumn{2}{|c|}{1,624} \\
\hline
\end{tabular}




\begin{tabular}{|c|c|c|c|c|c|c|}
\hline \multirow[b]{2}{*}{ VARIABLES } & \multicolumn{2}{|r|}{ (1) } & \multicolumn{2}{|c|}{ (2) } & \multicolumn{2}{|c|}{ (3) } \\
\hline & Coef & se & Coef & se & Coef & se \\
\hline Env Standard of Living & $0.19 * * *$ & $(0.04)$ & & & & \\
\hline Env Higher Taxes & & & $0.22 * * *$ & $(0.04)$ & & \\
\hline Economy v. Environment & & & & & $0.14 * * *$ & $(0.03)$ \\
\hline \multicolumn{7}{|l|}{ Party Close (FG) } \\
\hline $\mathrm{FF}$ & 0.10 & $(0.24)$ & 0.22 & $(0.23)$ & 0.21 & $(0.22)$ \\
\hline Labour & $-0.62 *$ & $(0.33)$ & $-0.51 *$ & $(0.30)$ & $-0.63 * *$ & $(0.31)$ \\
\hline SF & -0.32 & $(0.36)$ & -0.27 & $(0.34)$ & -0.34 & $(0.34)$ \\
\hline Other/None & $-0.58 * * *$ & $(0.18)$ & $-0.55 * * *$ & $(0.18)$ & $-0.60 * * *$ & $(0.17)$ \\
\hline \multicolumn{7}{|l|}{ Income $(<€ 20,000)$} \\
\hline$€ 20,000-24,999$ & 0.08 & $(0.29)$ & 0.11 & $(0.28)$ & 0.08 & $(0.28)$ \\
\hline$€ 25,000-29,999$ & 0.01 & $(0.33)$ & -0.05 & $(0.32)$ & -0.02 & $(0.32)$ \\
\hline$€ 30,000-34,999$ & -0.04 & $(0.30)$ & -0.19 & $(0.28)$ & -0.21 & $(0.28)$ \\
\hline$€ 35,000-39,999$ & 0.25 & $(0.34)$ & 0.21 & $(0.33)$ & 0.30 & $(0.32)$ \\
\hline$€ 40,000-49,999$ & 0.27 & $(0.30)$ & 0.29 & $(0.29)$ & 0.20 & $(0.29)$ \\
\hline$€ 50,000-69,999$ & 0.25 & $(0.30)$ & 0.24 & $(0.28)$ & 0.24 & $(0.28)$ \\
\hline$>€ 70,000$ & -0.14 & $(0.43)$ & -0.10 & $(0.39)$ & -0.13 & $(0.38)$ \\
\hline Refused to answer & -0.04 & $(0.22)$ & -0.05 & $(0.21)$ & -0.01 & $(0.21)$ \\
\hline \multicolumn{7}{|l|}{ Unemployed } \\
\hline Full Time Employed & 0.18 & $(0.25)$ & 0.16 & $(0.24)$ & 0.21 & $(0.24)$ \\
\hline Part Time Employed & 0.30 & $(0.29)$ & 0.28 & $(0.28)$ & 0.32 & $(0.27)$ \\
\hline Student & 0.41 & $(0.40)$ & $0.70 * *$ & $(0.35)$ & $0.79 * *$ & $(0.36)$ \\
\hline Retired & -0.04 & $(0.33)$ & -0.11 & $(0.31)$ & -0.02 & $(0.31)$ \\
\hline House Duties & -0.06 & $(0.32)$ & -0.00 & $(0.30)$ & -0.02 & $(0.30)$ \\
\hline \multicolumn{7}{|l|}{ House Owner/No Mortgage } \\
\hline Owner with loan/mortgage & $-0.32^{*}$ & $(0.17)$ & $-0.28^{*}$ & $(0.16)$ & -0.23 & $(0.16)$ \\
\hline Local Authority Tenant & $0.62 * *$ & $(0.26)$ & $0.74 * * *$ & $(0.25)$ & $0.71 * * *$ & $(0.25)$ \\
\hline Private Tenant & -0.28 & $(0.29)$ & -0.11 & $(0.27)$ & -0.03 & $(0.28)$ \\
\hline Other & $1.03 * *$ & $(0.51)$ & $0.85^{*}$ & $(0.49)$ & $0.90^{*}$ & $(0.50)$ \\
\hline Tax v. Spending & $0.12 * * *$ & $(0.03)$ & $0.11 * * *$ & $(0.03)$ & $0.12 * * *$ & $(0.03)$ \\
\hline Age & $0.02 * * *$ & $(0.01)$ & $0.02 * * *$ & $(0.01)$ & $0.02 * * *$ & $(0.01)$ \\
\hline Females & $-0.28 *$ & $(0.15)$ & -0.24 & $(0.15)$ & -0.22 & $(0.14)$ \\
\hline \multicolumn{7}{|l|}{ Education (primary) } \\
\hline Junior Certificate & $0.62 *$ & $(0.33)$ & 0.44 & $(0.31)$ & 0.44 & $(0.31)$ \\
\hline Leaving Certificate & $0.91 * * *$ & $(0.32)$ & $0.76^{* *}$ & $(0.30)$ & $0.81 * * *$ & $(0.30)$ \\
\hline Diploma/Certificate & $1.11 * * *$ & $(0.34)$ & $0.93 * * *$ & $(0.32)$ & $0.95 * * *$ & $(0.32)$ \\
\hline University & $1.23 * * *$ & $(0.34)$ & $1.16^{* * *}$ & $(0.32)$ & $1.21 * * *$ & $(0.32)$ \\
\hline \multicolumn{7}{|l|}{ Political Interest (Not at all) } \\
\hline Not Very & 0.06 & $(0.27)$ & -0.13 & $(0.25)$ & -0.13 & $(0.26)$ \\
\hline Quite Interested & 0.17 & $(0.27)$ & 0.07 & $(0.25)$ & 0.14 & $(0.25)$ \\
\hline Very Interested & $0.52 *$ & $(0.30)$ & 0.41 & $(0.28)$ & $0.47 *$ & $(0.28)$ \\
\hline Days listen to national radio per week & 0.03 & $(0.03)$ & 0.01 & $(0.03)$ & 0.03 & $(0.03)$ \\
\hline Constant & $-4.29 * * *$ & $(0.65)$ & $-4.15 * * *$ & $(0.60)$ & $-4.46^{* * *}$ & $(0.62)$ \\
\hline Psuedo $\mathrm{R}^{2}$ & \multicolumn{2}{|c|}{0.09} & \multicolumn{2}{|c|}{0.10} & \multicolumn{2}{|c|}{0.09} \\
\hline Observations & \multicolumn{2}{|c|}{1,540} & \multicolumn{2}{|c|}{1,696} & \multicolumn{2}{|c|}{1,701} \\
\hline
\end{tabular}




\begin{tabular}{|c|c|c|c|c|c|c|}
\hline \multirow[b]{2}{*}{ VARIABLES } & \multicolumn{2}{|r|}{ (1) } & \multicolumn{2}{|c|}{ (2) } & \multicolumn{2}{|c|}{ (3) } \\
\hline & Coef & se & Coef & $\mathrm{se}$ & Coef & se \\
\hline Env Standard of Living & $0.11 * * *$ & $(0.04)$ & & & & \\
\hline Env Higher Taxes & & & $0.10 * * *$ & $(0.03)$ & & \\
\hline Economy v. Environment & & & & & -0.04 & $(0.02)$ \\
\hline \multicolumn{7}{|l|}{ Party Close (FG) } \\
\hline FF & -0.30 & $(0.24)$ & -0.28 & $(0.23)$ & -0.30 & $(0.23)$ \\
\hline Labour & -0.05 & $(0.28)$ & 0.04 & $(0.27)$ & 0.02 & $(0.26)$ \\
\hline SF & -0.00 & $(0.32)$ & 0.00 & $(0.30)$ & -0.01 & $(0.30)$ \\
\hline Other/None & -0.08 & $(0.17)$ & -0.10 & $(0.16)$ & -0.14 & $(0.16)$ \\
\hline \multicolumn{7}{|l|}{ Income $(<€ 20,000)$} \\
\hline$€ 20,000-24,999$ & -0.31 & $(0.26)$ & -0.28 & $(0.25)$ & -0.27 & $(0.25)$ \\
\hline$€ 25,000-29,999$ & 0.38 & $(0.28)$ & $0.47 *$ & $(0.26)$ & 0.43 & $(0.27)$ \\
\hline$€ 30,000-34,999$ & 0.13 & $(0.25)$ & 0.20 & $(0.24)$ & 0.17 & $(0.24)$ \\
\hline$€ 35,000-39,999$ & 0.12 & $(0.30)$ & 0.04 & $(0.29)$ & 0.11 & $(0.29)$ \\
\hline$€ 40,000-49,999$ & -0.03 & $(0.27)$ & 0.13 & $(0.25)$ & 0.08 & $(0.25)$ \\
\hline$€ 50,000-69,999$ & 0.25 & $(0.26)$ & 0.37 & $(0.24)$ & 0.32 & $(0.24)$ \\
\hline$>€ 70,000$ & $0.76^{* *}$ & $0.35)$ & $0.84 * *$ & $(0.32)$ & $0.80 * *$ & $(0.32)$ \\
\hline Refused to answer & 0.01 & $(0.19)$ & 0.03 & $(0.18)$ & -0.01 & $(0.18)$ \\
\hline \multicolumn{7}{|l|}{ Unemployed } \\
\hline Full Time Employed & 0.34 & $(0.22)$ & $0.35^{*}$ & $(0.21)$ & $0.36^{*}$ & $(0.21)$ \\
\hline Part Time Employed & 0.23 & $(0.26)$ & 0.32 & $(0.24)$ & 0.31 & $(0.24)$ \\
\hline Student & $0.54 *$ & $(0.32)$ & 0.43 & $(0.30)$ & 0.46 & $(0.31)$ \\
\hline Retired & 0.12 & $(0.30)$ & 0.24 & $(0.28)$ & 0.22 & $(0.28)$ \\
\hline House Duties & 0.14 & $(0.27)$ & 0.34 & $(0.25)$ & 0.35 & $(0.25)$ \\
\hline \multicolumn{7}{|l|}{ House Owner/No Mortgage } \\
\hline Owner with loan/mortgage & $0.33 * *$ & $(0.15)$ & $0.29 * *$ & $(0.14)$ & $0.29 * *$ & $(0.14)$ \\
\hline Local Authority Tenant & $0.49 * *$ & $(0.24)$ & $0.51 * *$ & $(0.23)$ & $0.50 * *$ & $(0.23)$ \\
\hline Private Tenant & $0.50 * *$ & $(0.23)$ & $0.43^{*}$ & $(0.22)$ & $0.42 *$ & $(0.22)$ \\
\hline Other & 0.25 & $(0.44)$ & 0.36 & $(0.41)$ & 0.30 & $(0.41)$ \\
\hline Tax v. Spending & -0.13 & $(0.03)$ & -0.01 & $(0.03)$ & -0.00 & $(0.03)$ \\
\hline Age & 0.01 & $(0.01)$ & 0.00 & $(0.01)$ & 0.00 & $(0.01)$ \\
\hline Females & 0.09 & $(0.13)$ & 0.09 & $(0.12)$ & 0.09 & $(0.12)$ \\
\hline \multicolumn{7}{|l|}{ Education (primary) } \\
\hline Junior Certificate & 0.01 & $(0.27)$ & 0.05 & $(0.25)$ & 0.02 & $(0.25)$ \\
\hline Leaving Certificate & 0.03 & $(0.26)$ & 0.07 & $(0.25)$ & 0.04 & $(0.25)$ \\
\hline Diploma/Certificate & 0.00 & $(0.28)$ & 0.01 & $(0.26)$ & -0.00 & $(0.27)$ \\
\hline University & 0.02 & $(0.28)$ & 0.13 & $(0.27)$ & 0.16 & $(0.27)$ \\
\hline \multicolumn{7}{|l|}{ Political Interest (Not at all) } \\
\hline Not Very & -0.05 & $(0.22)$ & 0.04 & $(0.21)$ & 0.03 & $(0.21)$ \\
\hline Quite Interested & $0.42 *$ & $(0.22)$ & $0.42 * *$ & $(0.21)$ & $0.47 * *$ & $(0.20)$ \\
\hline Very Interested & 0.26 & $(0.26)$ & 0.37 & $(0.25)$ & $0.42 *$ & $(0.25)$ \\
\hline DK/No Reply & -0.36 & $(1.11)$ & -0.36 & $(1.01)$ & -0.38 & $(1.07)$ \\
\hline Days listen to national radio per week & -0.10 & $(0.03)$ & -0.01 & $(0.03)$ & 0.00 & $(0.02)$ \\
\hline Constant & $-1.66 * * *$ & $(0.52)$ & $-1.76 * * *$ & $(0.50)$ & $-1.29 * *$ & $(0.50)$ \\
\hline Psuedo $\mathrm{R}^{2}$ & 0.0 & & 0.0 & & 0. & \\
\hline Observations & 1,3 & & 1,5 & & 1,5 & \\
\hline
\end{tabular}

Robust standard errors in parentheses $* * * \mathrm{p}<0.01, * * \mathrm{p}<0.05, * \mathrm{p}<0.1$ 
Table A8: Logistic Regression of Support for Property Tax with Interactions

\begin{tabular}{|c|c|c|c|c|c|c|}
\hline \multirow[b]{2}{*}{ VARIABLES } & \multicolumn{2}{|c|}{ (1) } & \multicolumn{2}{|c|}{ (2) } & \multicolumn{2}{|c|}{ (3) } \\
\hline & Coef & $\mathrm{se}$ & Coef & $\mathrm{se}$ & Coef & se \\
\hline Env Standard of Living & $0.16^{*}$ & $(0.09)$ & & & & \\
\hline Env Higher Taxes & & & $0.17 * *$ & $(0.08)$ & & \\
\hline Economy v. Environment & & & & & $0.14 * *$ & $(0.06)$ \\
\hline Party Close (FG) & & & & & & \\
\hline FF & 0.49 & $(0.53)$ & 0.13 & $(0.49)$ & -0.04 & $(0.51)$ \\
\hline Labour & -1.27 & $(0.85)$ & $-1.55 * *$ & $(0.78)$ & -0.45 & $(0.79)$ \\
\hline SF & 0.18 & $(0.73)$ & 0.00 & $(0.69)$ & 0.77 & $(0.75)$ \\
\hline Other/None & $-0.87 * *$ & $(0.42)$ & $-0.79 * *$ & $(0.39)$ & -0.62 & $(0.41)$ \\
\hline Party Close $(\mathrm{FG}) *$ Env SoL & & & & & & \\
\hline FF & -0.11 & $(0.14)$ & & & & \\
\hline Labour & 0.17 & $(0.21)$ & & & & \\
\hline SF & -0.17 & $(0.20)$ & & & & \\
\hline Other/None & 0.08 & $(0.11)$ & & & & \\
\hline Party Close $(\mathrm{FG}) *$ Env Tax & & & & & & \\
\hline $\mathrm{FF}$ & & & 0.02 & $(0.13)$ & & \\
\hline Labour & & & 0.27 & $(0.19)$ & & \\
\hline SF & & & -0.09 & $(0.18)$ & & \\
\hline Other/None & & & 0.07 & $(0.10)$ & & \\
\hline Party Close $(\mathrm{FG})^{*}$ Env Econ & & & & & & \\
\hline FF & & & & & 0.05 & $(0.09)$ \\
\hline Labour & & & & & -0.03 & $(0.13)$ \\
\hline SF & & & & & -0.20 & $(0.13)$ \\
\hline Other/None & & & & & 0.00 & $(0.07)$ \\
\hline Income $(<€ 20,000)$ & & & & & & \\
\hline$€ 20,000-24,999$ & 0.07 & $(0.29)$ & 0.10 & $(0.28)$ & 0.08 & $(0.28)$ \\
\hline$€ 25,000-29,999$ & 0.01 & $(0.33)$ & -0.06 & $(0.32)$ & -0.04 & $(0.32)$ \\
\hline$€ 30,000-34,999$ & -0.04 & $(0.30)$ & -0.20 & $(0.28)$ & -0.22 & $(0.29)$ \\
\hline$€ 35,000-39,999$ & 0.20 & $(0.35)$ & 0.19 & $(0.33)$ & 0.30 & $(0.32)$ \\
\hline$€ 40,000-49,999$ & 0.24 & $(0.31)$ & 0.30 & $(0.29)$ & 0.20 & $(0.29)$ \\
\hline$€ 50,000-69,999$ & 0.22 & $(0.30)$ & 0.24 & $(0.28)$ & 0.24 & $(0.28)$ \\
\hline$>€ 70,000$ & -0.15 & $(0.42)$ & -0.13 & $(0.40)$ & -0.13 & $(0.38)$ \\
\hline Refused to answer & -0.06 & $(0.22)$ & -0.05 & $(0.21)$ & -0.01 & $(0.21)$ \\
\hline Unemployed & & & & & & \\
\hline Full Time Employed & 0.20 & $(0.26)$ & 0.18 & $(0.24)$ & 0.19 & $(0.24)$ \\
\hline Part Time Employed & 0.33 & $(0.29)$ & 0.30 & $(0.28)$ & 0.29 & $(0.27)$ \\
\hline Student & 0.42 & $(0.40)$ & $0.70 * *$ & $(0.35)$ & $0.79 * *$ & $(0.36)$ \\
\hline Retired & -0.02 & $(0.33)$ & -0.10 & $(0.31)$ & -0.04 & $(0.31)$ \\
\hline House Duties & -0.05 & $(0.32)$ & 0.01 & $(0.31)$ & -0.04 & $(0.31)$ \\
\hline
\end{tabular}

House Owner/No Mortgage 


\begin{tabular}{|c|c|c|c|c|c|c|}
\hline Owner with loan/mortgage & $-0.32 *$ & $(0.17)$ & $-0.28 *$ & $(0.16)$ & -0.23 & $(0.16)$ \\
\hline Local Authority Tenant & $0.62 * *$ & $(0.27)$ & $0.77 * * *$ & $(0.26)$ & $0.66 * * *$ & $(0.25)$ \\
\hline Private Tenant & -0.28 & $(0.30)$ & -0.12 & $(0.27)$ & -0.01 & $(0.28)$ \\
\hline Other & $0.98 *$ & $(0.51)$ & $0.81 *$ & $(0.49)$ & $0.89 *$ & $(0.50)$ \\
\hline Tax v. Spending & $0.13 * * *$ & $(0.03)$ & $0.11 * * *$ & $(0.03)$ & $0.12 * * *$ & $(0.03)$ \\
\hline Age & $0.02 * * *$ & $(0.01)$ & $0.02 * * *$ & $(0.01)$ & $0.02 * * *$ & $(0.01)$ \\
\hline Females & $-0.27 *$ & $(0.15)$ & $-0.25^{*}$ & $(0.15)$ & -0.21 & $(0.15)$ \\
\hline Education (primary) & & & & & & \\
\hline Junior Certificate & $0.64 * *$ & $(0.32)$ & 0.43 & $(0.31)$ & 0.44 & $(0.31)$ \\
\hline Leaving Certificate & $0.92 * * *$ & $(0.32)$ & $0.78 * * *$ & $(0.30)$ & $0.81 * * *$ & $(0.30)$ \\
\hline Diploma/Certificate & $1.13 * * *$ & $(0.34)$ & $0.94 * * *$ & $(0.32)$ & $0.94 * * *$ & $(0.32)$ \\
\hline University & $1.24 * * *$ & $(0.34)$ & $1.17 * * *$ & $(0.32)$ & $1.21 * * *$ & $(0.32)$ \\
\hline Political Interest (Not at all) & & & & & & \\
\hline Not Very & 0.08 & $(0.28)$ & -0.15 & $(0.26)$ & -0.13 & $(0.26)$ \\
\hline Quite Interested & 0.16 & $(0.27)$ & 0.06 & $(0.25)$ & 0.14 & $(0.25)$ \\
\hline Very Interested & $0.51 *$ & $(0.30)$ & 0.41 & $(0.28)$ & $0.49 *$ & $(0.28)$ \\
\hline Days listen to national radio per week & 0.02 & $(0.03)$ & 0.01 & $(0.03)$ & 0.03 & $(0.03)$ \\
\hline Constant & $-4.18 * * *$ & $(0.71)$ & $-4.01 * * *$ & $(0.66)$ & $-4.44 * * *$ & $(0.69)$ \\
\hline Pseudo- $\mathrm{R}^{2}$ & \multicolumn{2}{|c|}{0.10} & \multicolumn{2}{|c|}{0.10} & \multicolumn{2}{|c|}{0.09} \\
\hline Observations & \multicolumn{2}{|c|}{1,540} & \multicolumn{2}{|c|}{1,696} & \multicolumn{2}{|c|}{1,701} \\
\hline
\end{tabular}

Robust standard errors in parentheses $* * * \mathrm{p}<0.01, * * \mathrm{p}<0.05, * \mathrm{p}<0.1$ 
Table A9: Multinomial Logistic Regression on First Preference Vote/Vote Intention for 2011 General Election

\begin{tabular}{|c|c|c|c|c|c|c|c|c|c|c|c|c|}
\hline$\frac{\text { VARIABLES }}{\text { Reference FG }}$ & \multicolumn{2}{|c|}{$\begin{array}{l}(1) \\
\text { FF }\end{array}$} & \multicolumn{2}{|c|}{$\begin{array}{c}(2) \\
\mathrm{LAB}\end{array}$} & \multicolumn{2}{|c|}{$\begin{array}{l}(3) \\
\text { SF }\end{array}$} & \multicolumn{2}{|c|}{$\begin{array}{l}(4) \\
\text { Ind }\end{array}$} & \multicolumn{2}{|c|}{$\begin{array}{l}(5) \\
\text { Other }\end{array}$} & \multicolumn{2}{|c|}{$\begin{array}{c}(6) \\
\text { Refused/Don't Know }\end{array}$} \\
\hline Support Water Tax & -0.15 & $(0.18)$ & $-0.33 * *$ & $(0.16)$ & $-1.27 * * *$ & $(0.25)$ & -0.31 & $(0.20)$ & -0.13 & $(0.26)$ & -0.21 & $(0.27)$ \\
\hline Income $(<€ 20,000)$ & & & & & & & & & & & & \\
\hline$€ 20,000-24,999$ & -0.38 & $(0.36)$ & $-0.75 * *$ & $(0.33)$ & -0.51 & $(0.36)$ & 0.15 & $(0.42)$ & -0.41 & $(0.45)$ & 0.46 & $(0.62)$ \\
\hline$€ 25,000-29,999$ & 0.43 & $(0.39)$ & -0.09 & $(0.35)$ & -0.04 & $(0.40)$ & 0.57 & $(0.47)$ & 0.12 & $(0.51)$ & $1.09 *$ & $(0.66)$ \\
\hline$€ 30,000-34,999$ & -0.02 & $(0.34)$ & $-0.82 * *$ & $(0.33)$ & $-1.13 * * *$ & $(0.42)$ & 0.57 & $(0.39)$ & $-0.88^{*}$ & $(0.53)$ & 0.22 & $(0.65)$ \\
\hline$€ 35,000-39,999$ & -0.22 & $(0.42)$ & $-0.65 *$ & $(0.39)$ & -0.74 & $(0.51)$ & -0.07 & $(0.51)$ & -0.14 & $(0.55)$ & 0.76 & $(0.67)$ \\
\hline$€ 40,000-49,999$ & $-0.84 * *$ & $(0.41)$ & $-1.00 * * *$ & $(0.35)$ & $-1.19 * *$ & $(0.46)$ & -0.36 & $(0.47)$ & -0.65 & $(0.52)$ & 0.25 & $(0.69)$ \\
\hline$€ 50,000-69,999$ & $-0.68 *$ & $(0.39)$ & -0.46 & $(0.32)$ & $-1.21 * *$ & $(0.51)$ & -0.01 & $(0.44)$ & -0.32 & $(0.46)$ & 0.07 & $(0.71)$ \\
\hline$>€ 70,000$ & 0.16 & $(0.51)$ & -0.59 & $(0.43)$ & $-13.95 * * *$ & $(0.40)$ & 0.19 & $(0.56)$ & -0.99 & $(0.73)$ & 0.16 & $(0.86)$ \\
\hline Refused to answer & $-0.58 * *$ & $(0.28)$ & $-0.54 * *$ & $(0.24)$ & $-0.87 * * *$ & $(0.27)$ & -0.00 & $(0.32)$ & $-1.26 * * *$ & $(0.38)$ & 0.63 & $(0.50)$ \\
\hline Unemployed & & & & & & & & & & & & \\
\hline Full Time Employed & 0.18 & $(0.32)$ & $0.52 *$ & $(0.28)$ & -0.45 & $(0.32)$ & -0.01 & $(0.35)$ & -0.35 & $(0.43)$ & -0.38 & $(0.47)$ \\
\hline Part Time Employed & -0.08 & $(0.38)$ & $0.65 * *$ & $(0.32)$ & -0.16 & $(0.35)$ & $0.73 * *$ & $(0.37)$ & -0.25 & $(0.49)$ & -0.35 & $(0.56)$ \\
\hline Student & -0.10 & $(0.55)$ & -0.18 & $(0.43)$ & 0.09 & $(0.43)$ & -0.33 & $(0.52)$ & -0.08 & $(0.55)$ & -1.04 & $(0.87)$ \\
\hline Retired & 0.59 & $(0.39)$ & $0.80 * *$ & $(0.37)$ & -0.18 & $(0.45)$ & 0.77 & $(0.48)$ & 0.80 & $(0.54)$ & 0.70 & $(0.65)$ \\
\hline House Duties & -0.20 & $(0.37)$ & -0.22 & $(0.34)$ & -0.46 & $(0.37)$ & 0.08 & $(0.41)$ & -0.14 & $(0.50)$ & -0.88 & $(0.60)$ \\
\hline Age & -0.01 & $(0.01)$ & -0.01 & $(0.01)$ & $-0.02 * *$ & $(0.01)$ & -0.01 & $(0.01)$ & $-0.02 *$ & $(0.01)$ & -0.00 & $(0.01)$ \\
\hline Female & -0.18 & $(0.19)$ & 0.03 & $(0.16)$ & -0.25 & $(0.21)$ & -0.14 & $(0.21)$ & 0.11 & $(0.27)$ & -0.13 & $(0.28)$ \\
\hline Education (primary) & & & & & & & & & & & & \\
\hline Junior Certificate & -0.11 & $(0.31)$ & 0.55 & $(0.37)$ & $0.84 * *$ & $(0.39)$ & $1.08^{*}$ & $(0.56)$ & 0.41 & $(0.56)$ & $2.15^{*}$ & $(1.14)$ \\
\hline Leaving Certificate & -0.34 & $(0.32)$ & $0.77 * *$ & $(0.36)$ & 0.47 & $(0.40)$ & $1.25^{* *}$ & $(0.55)$ & 0.44 & $(0.53)$ & $2.78 * *$ & $(1.15)$ \\
\hline Diploma/Certificate & $-0.66^{*}$ & $(0.35)$ & 0.37 & $(0.38)$ & 0.32 & $(0.45)$ & $1.24 * *$ & $(0.58)$ & 0.48 & $(0.56)$ & $2.39 * *$ & $(1.17)$ \\
\hline University & $-0.90 * *$ & $(0.38)$ & 0.60 & $(0.39)$ & 0.24 & $(0.49)$ & $1.53 * * *$ & $(0.58)$ & 0.34 & $(0.58)$ & $2.40 * *$ & $(1.17)$ \\
\hline Married & & & & & & & & & & & & \\
\hline Living as married & $0.53 *$ & $(0.29)$ & 0.15 & $(0.27)$ & $0.83 * *$ & $(0.33)$ & 0.37 & $(0.33)$ & 0.01 & $(0.48)$ & 0.60 & $(0.42)$ \\
\hline Single & -0.12 & $(0.24)$ & 0.10 & $(0.21)$ & -0.00 & $(0.29)$ & 0.23 & $(0.25)$ & -0.06 & $(0.35)$ & -0.21 & $(0.43)$ \\
\hline Divorced/Widowed/Separated & 0.42 & $(0.28)$ & 0.24 & $(0.28)$ & $0.57 *$ & $(0.32)$ & $0.64 *$ & $(0.33)$ & 0.08 & $(0.45)$ & 0.42 & $(0.44)$ \\
\hline
\end{tabular}


Social Class (AB)

\begin{tabular}{|c|c|c|c|c|c|c|c|c|c|c|c|c|}
\hline $\mathrm{C} 1$ & -0.06 & $(0.26)$ & 0.26 & $(0.23)$ & 0.15 & $(0.38)$ & 0.21 & $(0.29)$ & -0.17 & $(0.40)$ & 0.20 & $(0.39)$ \\
\hline $\mathrm{C} 2$ & -0.15 & $(0.30)$ & 0.28 & $(0.26)$ & 0.55 & $(0.39)$ & 0.16 & $(0.32)$ & -0.19 & $(0.41)$ & -0.31 & $(0.45)$ \\
\hline $\mathrm{D}$ & 0.14 & $(0.33)$ & 0.11 & $(0.30)$ & 0.46 & $(0.43)$ & 0.19 & $(0.37)$ & 0.20 & $(0.44)$ & 0.39 & $(0.48)$ \\
\hline $\mathrm{E}$ & -0.07 & $(0.37)$ & 0.33 & $(0.36)$ & 0.74 & $(0.46)$ & 0.01 & $(0.46)$ & 0.22 & $(0.49)$ & 0.59 & $(0.57)$ \\
\hline $\mathrm{F} 50+$ & -0.66 & $(0.41)$ & $-1.67 * * *$ & $(0.60)$ & -0.77 & $(0.58)$ & 0.01 & $(0.42)$ & -1.53 & (1.11) & -0.60 & $(0.72)$ \\
\hline F 50 - & -0.16 & $(0.64)$ & -0.91 & (1.11) & 0.57 & $(0.77)$ & 0.61 & $(0.77)$ & 0.11 & (1.08) & $1.55^{*}$ & $(0.80)$ \\
\hline $\begin{array}{l}\text { Area }(\text { Town/City }>1,500) \\
\text { Town/Village/Rural } \\
(<1,500)\end{array}$ & 0.24 & $(0.17)$ & $-0.44 * * *$ & $(0.16)$ & $0.53 * * *$ & $(0.19)$ & $0.51 * * *$ & $(0.19)$ & $-0.57 * *$ & $(0.28)$ & $0.92 * * *$ & $(0.28)$ \\
\hline Political knowledge & $0.20 * *$ & $(0.10)$ & -0.09 & $(0.09)$ & 0.03 & $(0.11)$ & -0.16 & $(0.11)$ & 0.05 & $(0.14)$ & $-0.41 * *$ & $(0.18)$ \\
\hline Belief in God & $0.11 * * *$ & $(0.03)$ & $-0.07 * * *$ & $(0.03)$ & -0.05 & $(0.04)$ & -0.05 & $(0.03)$ & $-0.11 * * *$ & $(0.04)$ & -0.01 & $(0.06)$ \\
\hline $\begin{array}{l}\text { MII (Failure of Political } \\
\text { System) }\end{array}$ & & & & & & & & & & & & \\
\hline Public Services & $0.71 * *$ & $(0.30)$ & 0.25 & $(0.24)$ & 0.21 & $(0.32)$ & 0.14 & $(0.30)$ & 0.34 & $(0.37)$ & -0.18 & $(0.49)$ \\
\hline Economy/Public Finances & $0.67 * *$ & $(0.26)$ & 0.15 & $(0.22)$ & $0.70 * *$ & $(0.28)$ & -0.04 & $(0.28)$ & -0.37 & $(0.38)$ & 0.28 & $(0.38)$ \\
\hline Employment/Labour & $0.74 * * *$ & $(0.28)$ & $0.73 * * *$ & $(0.21)$ & $0.58 * *$ & $(0.29)$ & 0.30 & $(0.27)$ & 0.20 & $(0.36)$ & -0.13 & $(0.43)$ \\
\hline Taxes/Pension Cuts & $0.77 * *$ & $(0.35)$ & 0.24 & $(0.31)$ & -0.20 & $(0.42)$ & -0.04 & $(0.40)$ & 0.20 & $(0.45)$ & 0.05 & $(0.56)$ \\
\hline Other/Don’t Know & $0.74 * *$ & $(0.35)$ & 0.07 & $(0.33)$ & 0.15 & $(0.41)$ & -0.47 & $(0.46)$ & -0.20 & $(0.48)$ & 0.46 & $(0.48)$ \\
\hline $\begin{array}{l}\text { Gov Policy Mainly } \\
\text { Responsible for Econ } \\
\text { Change (Yes) }\end{array}$ & & & & & & & & & & & & \\
\hline No & $1.97 * * *$ & $(0.22)$ & 0.02 & $(0.28)$ & 0.35 & $(0.34)$ & $0.56 *$ & $(0.31)$ & 0.22 & $(0.49)$ & 0.07 & $(0.49)$ \\
\hline No answer/DK/Missing & $1.42 * * *$ & $(0.29)$ & -0.06 & $(0.33)$ & 0.52 & $(0.34)$ & -0.02 & $(0.41)$ & $1.04 * * *$ & $(0.38)$ & 0.64 & $(0.41)$ \\
\hline Constant & $-1.88 * * *$ & $(0.73)$ & -0.20 & $(0.70)$ & -0.32 & $(0.83)$ & $-1.84 * *$ & $(0.91)$ & 0.26 & $(1.09)$ & $-4.51 * * *$ & $(1.41)$ \\
\hline Pseudo R ${ }^{2}$ & \multirow{2}{*}{\multicolumn{12}{|c|}{$\begin{array}{c}0.12 \\
1,786 \\
\end{array}$}} \\
\hline Observations & & & & & & & & & & & & \\
\hline
\end{tabular}


Table A10: Multinomial Logistic Regression on First Preference Vote/Vote Intention for 2011 General Election with past vote

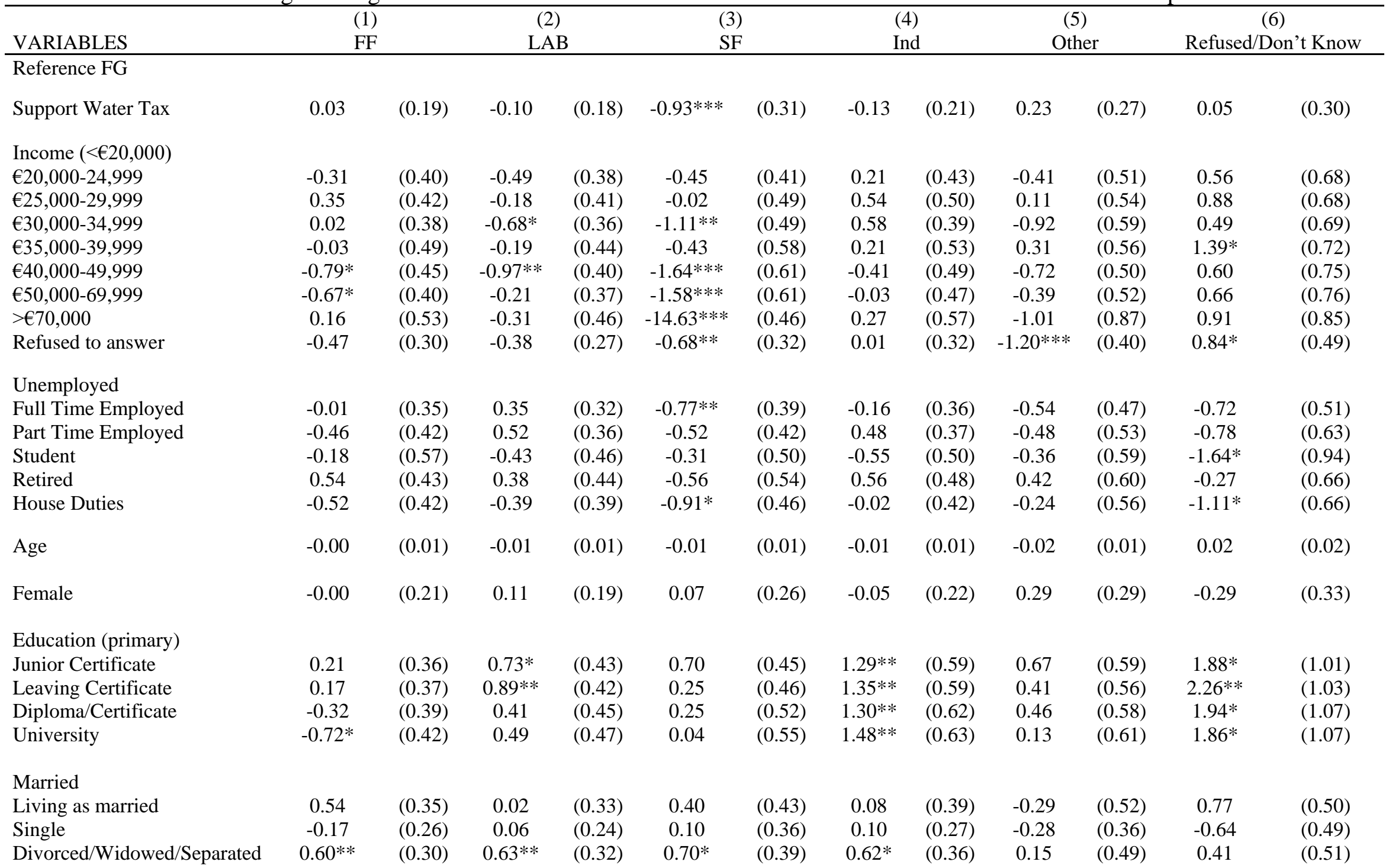




\begin{tabular}{|c|c|c|c|c|c|c|c|c|c|c|c|c|}
\hline Social Class (AB) & & & & & & & & & & & & \\
\hline $\mathrm{C} 1$ & -0.08 & $(0.28)$ & 0.31 & $(0.28)$ & 0.05 & $(0.46)$ & 0.28 & $(0.30)$ & -0.16 & $(0.40)$ & -0.01 & $(0.40)$ \\
\hline $\mathrm{C} 2$ & -0.22 & $(0.32)$ & 0.15 & $(0.30)$ & 0.54 & $(0.47)$ & 0.12 & $(0.34)$ & -0.31 & $(0.43)$ & -0.68 & $(0.50)$ \\
\hline $\mathrm{D}$ & -0.00 & $(0.36)$ & -0.03 & $(0.36)$ & 0.27 & $(0.52)$ & 0.15 & $(0.39)$ & 0.10 & $(0.48)$ & 0.17 & $(0.52)$ \\
\hline $\mathrm{E}$ & -0.26 & $(0.43)$ & 0.04 & $(0.43)$ & 0.29 & $(0.58)$ & -0.08 & $(0.46)$ & 0.03 & $(0.51)$ & -0.16 & $(0.61)$ \\
\hline $\mathrm{F} 50+$ & -0.46 & $(0.44)$ & $-1.46^{* *}$ & $(0.58)$ & -0.78 & $(0.68)$ & -0.00 & $(0.44)$ & -1.42 & (1.14) & -1.00 & $(0.83)$ \\
\hline F $50-$ & -0.36 & $(0.66)$ & -0.61 & (1.09) & -0.20 & $(1.15)$ & 0.74 & $(0.74)$ & 0.48 & (1.10) & $1.78 * *$ & $(0.88)$ \\
\hline Area $($ Town/City >1,500) & & & & & & & & & & & & \\
\hline Town/Village/Rural $(<1,500)$ & $0.34 *$ & $(0.19)$ & -0.17 & $(0.18)$ & $0.58 * *$ & $(0.23)$ & $0.60 * * *$ & $(0.20)$ & -0.46 & $(0.30)$ & $1.06^{* * *}$ & $(0.29)$ \\
\hline Political knowledge & 0.15 & $(0.12)$ & -0.06 & $(0.10)$ & 0.12 & $(0.14)$ & -0.15 & $(0.12)$ & 0.08 & $(0.15)$ & -0.06 & $(0.19)$ \\
\hline Belief in God & $0.09 * *$ & $(0.04)$ & -0.05 & $(0.03)$ & -0.01 & $(0.04)$ & -0.03 & $(0.03)$ & -0.07 & $(0.05)$ & 0.04 & $(0.06)$ \\
\hline MII (Failure of Political System) & & & & & & & & & & & & \\
\hline Public Services & $0.88 * * *$ & $(0.32)$ & $0.48 *$ & $(0.28)$ & -0.01 & $(0.39)$ & 0.28 & $(0.31)$ & 0.55 & $(0.39)$ & -0.30 & $(0.54)$ \\
\hline Economy/Public Finances & $0.80 * * *$ & $(0.28)$ & 0.32 & $(0.27)$ & $0.84 * *$ & $(0.33)$ & 0.02 & $(0.29)$ & -0.27 & $(0.41)$ & 0.36 & $(0.41)$ \\
\hline Employment/Labour & $0.95 * * *$ & $(0.31)$ & $0.85 * * *$ & $(0.26)$ & 0.38 & $(0.36)$ & 0.34 & $(0.28)$ & 0.32 & $(0.38)$ & -0.06 & $(0.43)$ \\
\hline Other/Don’t Know & $0.99 * * *$ & $(0.35)$ & 0.21 & $(0.38)$ & 0.00 & $(0.51)$ & -0.39 & $(0.47)$ & -0.06 & $(0.49)$ & 0.17 & $(0.49)$ \\
\hline $\begin{array}{l}\text { Gov Policy Mainly Responsible } \\
\text { for Econ Change (Yes) }\end{array}$ & & & & & & & & & & & & \\
\hline No & $1.61 * * *$ & $(0.24)$ & 0.05 & $(0.31)$ & 0.44 & $(0.45)$ & 0.47 & $(0.33)$ & -0.12 & $(0.51)$ & -0.26 & $(0.47)$ \\
\hline No answer/DK/Missing & $1.34 * * *$ & $(0.31)$ & 0.12 & $(0.36)$ & 0.61 & $(0.38)$ & -0.03 & $(0.42)$ & $1.05^{* *}$ & $(0.41)$ & 0.10 & $(0.43)$ \\
\hline Vote 2007 Election (FG) & & & & & & & & & & & & \\
\hline $\mathrm{FF}$ & $3.74 * * *$ & $(0.40)$ & $1.63 * * *$ & $(0.26)$ & $1.31 * * *$ & $(0.39)$ & $1.37 * * *$ & $(0.28)$ & $2.84 * * *$ & $(0.75)$ & $1.23 * *$ & $(0.50)$ \\
\hline Labour & $1.62 *$ & $(0.88)$ & $4.32 * * *$ & $(0.33)$ & $2.63 * * *$ & $(0.54)$ & $2.00 * * *$ & $(0.46)$ & $4.68 * * *$ & $(0.79)$ & $-12.28 * * *$ & $(0.44)$ \\
\hline $\mathrm{SF}$ & $-20.63 * * *$ & $(0.68)$ & $2.85 * * *$ & $(0.70)$ & $6.37 * * *$ & $(0.66)$ & $2.97 * * *$ & $(0.71)$ & $5.31 * * *$ & $(0.98)$ & $3.48 * * *$ & $(0.98)$ \\
\hline Ind/Other & $2.45^{* * *}$ & $(0.70)$ & $2.01 * * *$ & $(0.43)$ & 0.98 & $(0.83)$ & $3.02 * * *$ & $(0.39)$ & $5.47 * * *$ & $(0.77)$ & 1.31 & (1.11) \\
\hline Don't Know/Didn't Vote & $2.38 * * *$ & $(0.46)$ & $1.67 * * *$ & $(0.29)$ & $2.02 * * *$ & $(0.40)$ & $1.29 * * *$ & $(0.33)$ & $3.17 * * *$ & $(0.77)$ & $3.86 * * *$ & $(0.48)$ \\
\hline Constant & $-4.98 * * *$ & $(0.86)$ & $-2.37 * * *$ & $(0.88)$ & $-2.62 * *$ & $(1.17)$ & $-3.41 * * *$ & $(1.01)$ & $-3.33 * *$ & $(1.39)$ & $-7.76 * * *$ & $(1.34)$ \\
\hline Pseudo $\mathrm{R}^{2}$ & & & & & & & & & & & & \\
\hline Observations & & & & & & & & & & & & \\
\hline
\end{tabular}

Robust standard errors in parentheses

$* * * \mathrm{p}<0.01, * * \mathrm{p}<0.05, * \mathrm{p}<0.1$ 